\title{
ATOMIZATION AS COLONIAL STRATEGY IN PALESTINE
}

\author{
By
}

Christian Alexander Brawner

B.A. University of Louisville, 2016

\author{
A Thesis \\ Submitted to the Faculty of the \\ College of Arts and Sciences of the University of Louisville \\ In Partial Fulfillment of the Requirements \\ For the Degree of
}

\author{
Master of Arts \\ in Anthropology \\ Department of Anthropology \\ University of Louisville \\ Louisville, Kentucky
}

May 2020 

ATOMIZATION AS COLONIAL STRATEGY IN PALESITINE

By

Christian Alexander Brawner

B.A. University of Louisville, 2016

A Thesis Approved on

April 20, 2020

by the following Thesis Committee

Julie Peteet, Ph.D.

Angela D. Storey, Ph.D.

Brad Bowman, Ph.D. 


\section{ABSTRACT \\ ATOMIZATION AS COLONIAL STRATEGY IN PALESTINE \\ Christian Alexander Brawner}

April 20, 2020

Walid Daka, a Palestinian political prisoner in Israel since 1986, contends that Israel's "final solution" to quell Palestinian resistance is currently unfolding in Israeli prisons where, as he describes, Palestinian prisoners are being divided from one another through seemingly unrelated actions and policies. Daka argues that current Israeli practices have replaced traditional physical brutality with seemingly harmless administrative decisions and actions taken by prison authorities that are aimed at instilling mistrust among Palestinians, substituting collective struggle and solidarity with individualized interests, and altering Palestinians' awareness of national struggle. As Daka puts it, it is a set of endeavors to remold Palestinian political and social consciousness. This strategy of pitting people against people, breaking social cohesion, and producing self-involved individuals in order to dominate, exploit, and create a quiescent population can be referred to as a policy of atomization. While this is not a new idea confined to Israel's occupation of Palestine, atomization instead exists throughout the history of western colonialism and industrial capitalism and can be traced through the discourse of various social theorists such as Max Weber, Émile Durkheim, Karl Marx and their successors. What is new, however, is the material ways in which states, being the physical force and manifestation of capitalists, and non-state actors (NGOs), can inflict atomization upon groups they seek to dominate or coerce into participating in capitalist exploitation that is the result of the 
technological advancements and the ever-expanding and consuming nature of capitalism itself. This thesis defines atomization in the contemporary context of Palestinian prisoners in Israel and traces the contributions of western social theorists in order to explore atomization as a product of a dialectical history that is essential to the domination and disciplining of the working classes under capitalism and Palestinians under Israeli settler-colonialism and occupation. 


\section{TABLE OF CONTENTS}

ABSTRACT

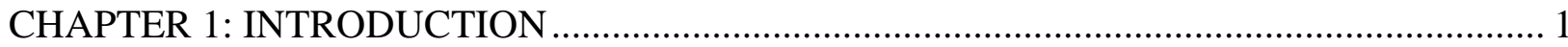

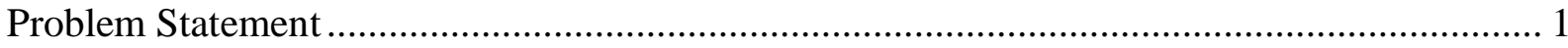

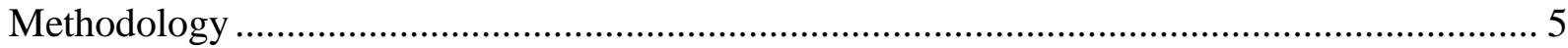

Historical Background: The Colonization of Palestine ............................................................. 6

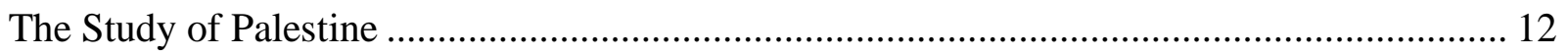

Literature Review: Atomization in European History ........................................................... 14

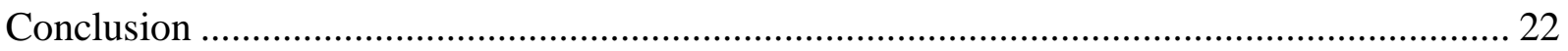

CHAPTER 2: APARTNESS AS STRUCTURE THROUGH DISCOURSE AND ACTION .... 24

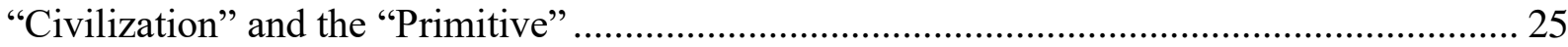

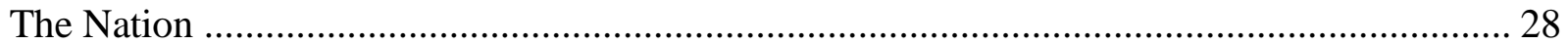

Evidence of Discursive Division Pre-State: Books, Films, and Maps..................................... 33

CHAPTER 3: COLONIZING LAND, BODIES, AND SOULS: ISRAEL'S ATOMIZATION OF

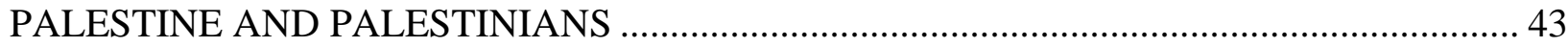

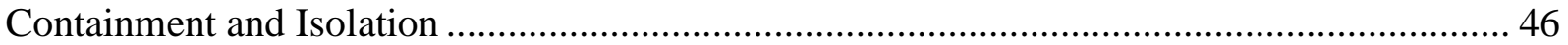

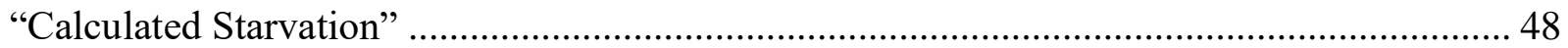

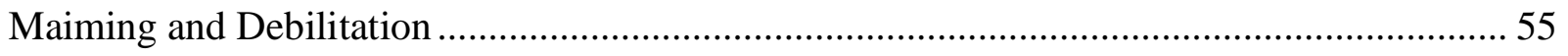

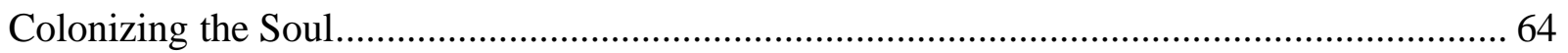

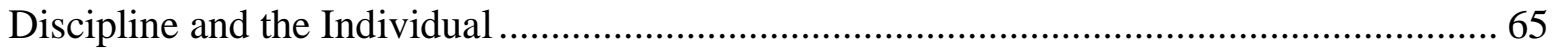

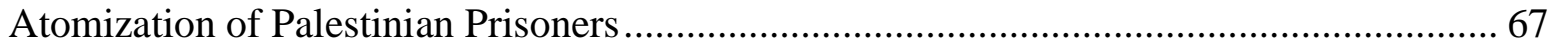

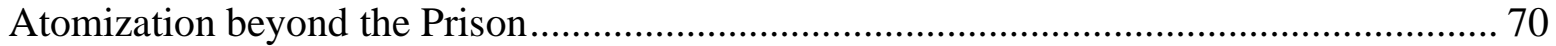

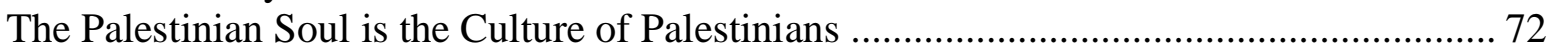

Violence, Dispossession, Atomization, and Discipline as Historical and Present.................... 75

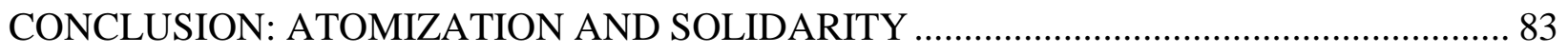

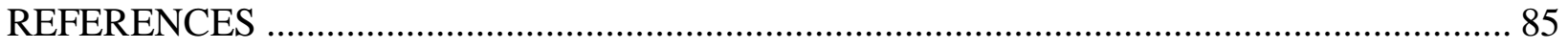

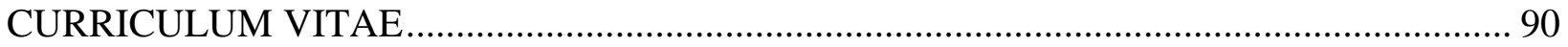




\section{CHAPTER 1: INTRODUCTION}

\section{Problem Statement}

On September 10, 2019, in the face of a tight election race, Israel's Prime Minister Benjamin Netanyahu announced plans to annex all Israeli settlements in the West Bank and the rest of the Jordan Valley, further solidifying Israel's enclosure of what remains of Palestine. As described by Julie Peteet in Space and Mobility in Palestine (2017), Israeli policies of enclosure separate and divide Palestinian communities denying them connections with one another and with their land. The structural enclosures in the West Bank create an archipelago of small communities intersected by walls, checkpoints, and colonizer-exclusive roads. By separating Palestinians spatially, then controlling, monitoring, and curtailing their movements between these spaces, Israel dominates Palestinians’ lives in space and time.) Palestinians remain steadfast, pensively and anxiously waiting for liberation while Israel moves at ever faster rates to carve up their land and communities, holding Palestinians imprisoned in a "prolonged stasis." But to what end? Palestinian political prisoner, Walid Daka (2011: 238) theorizes that the enclaves themselves "...consist of the final solution," where the body is no longer the target; not collective extermination but instead the absolute decimation of "the soul - the extermination of the Palestinian culture and civilization." In Daka's theory, the colonization of Palestine will only be complete with the breaking and remolding of Palestinian consciousness from a culture of solidarity and resistance to one of individualism and compliance. His theory stems from his own experience in the Israeli Prison Service (IPS) where newly instituted policies ultimately severed the social and political unity of Palestinian leaders and comrades in detention, decimating solidarity and thus their strength to organize and resist. I call this strategy atomization as it works 
to break down people and cultures into individual components, rearranging them into different forms. Atomization occurs through violence, through severing ties to their land, to their sustenance, to their health, and shattering their collective unity, and memory, against their oppressors. In order to understand the possible future projections of the Zionist colonization of Palestine, and to ultimately stop Daka's theorized decimation of Palestinian resistance in the OPTs, an investigation of the current Israeli state and occupation of Palestine should be examined through applying and expanding on atomization.

In 2006, former Israeli chief of staff, Moshe Ya'alon, declared publicly in Israeli media outlets that "the Palestinian consciousness must be remolded, and that this goal dictated his army’s plans" (ibid.: 236-237). This declaration was a public statement of the Israeli strategy to defeat Palestinian resistance. The tactics of this strategy include massive and intermittent violence that shocks populations and keeps them in a state of terror, dispossession of Palestinians from their land and means of subsistence through legal procedures and force, and the physical and legal division of Palestinians within the OPTs through a system of walls, checkpoints, and permits. Daka argues that since the end of the second Intifada, "the new targets were the elements of the moral infrastructure of the resistance... the collective values that embodies the concept of one unified people," the target became the very substance that is shared between Palestinians and what makes them Palestinian (ibid.: 237).

Walid Daka, Palestinian political prisoner since 1986, has theorized that Israel's “final solution" to end Palestinian resistance is currently unfolding in Israeli prisons where, as he describes, Palestinian prisoners are being divided from one another through seemingly unrelated actions and policies. Daka argues that current Israeli practices replace traditional brutality with seemingly harmless decisions by prison administrators that function to instill mistrust between 
Palestinians, substitute group struggle with private interests, and alter Palestinians' awareness of national struggle, or as Daka puts it, remolding the Palestinian consciousness. This strategy of pitting people against people, breaking social cohesion, and producing self-involved individuals in order to dominate and exploit them is what I call atomization. While this is not a new idea confined to Israel's occupation of Palestine, atomization instead exists throughout the history of western colonialism and industrial capitalism and can be traced through the discourse of various social theorists such as Max Weber, Emile Durkheim, Karl Marx and their successors. What is new, is the material ways in which states, being the physical force and manifestation of capitalists, and non-state actors (NGOs), can inflict atomization upon groups they seek to dominate or coerce into participating in capitalist exploitation that is the result of the technological advancements and the ever-expanding and consuming nature of capitalism itself. This thesis defines atomization in the contemporary context of Palestinian prisoners in Israel and traces the contributions of western social theorists in order to reveal atomization as a product of a dialectical history that is essential to the domination and discipline of the working classes under capitalism and Palestinians under Israeli occupation.

What I call atomization materialized from discussions with my mentor about Walid Daka's exceptional chapter in an anthology on Palestinian political prisoners in Israel titled: “Consciousness Molded or the Re-identification of Torture.” In 1986, Daka was accused and tried for the murder of an Israeli soldier and for membership in the Popular Front for the Liberation of Palestine (PFLP), a Marxist-Leninist revolutionary party. He deploys his knowledge of political theory and his own experiences and observations within the IPS, to suggest the means by which the Israeli state is attempting to end Palestinian resistance. Daka argues that the Israeli prison is the site, the laboratory of experimentation, where tactics are 
devised to dominate, dispossess, and control Palestinians. The enclaves in the West Bank and the entire enclosure of Gaza that separate Palestinians from one another and the outside world are a direct reflection of the prisons that separate Palestinians into wings and cells, limiting their communication and mobility. More importantly, as Daka describes, the similarity between the Palestinian in prison and the enclosed Palestinian "...relates to the purpose of the jailer: to remold them according to an Israeli vision" (2011: 235). Daka suggests that the goal of the state and the jailer, is to remake the Palestinian into a docile subject (ibid.: 236).

The strategy that Israel has found successful within its prisons and is implementing throughout the OPT is what I characterize as atomization, or the breaking up of a cohesive social body into individuals. Atomization is often used in particle physics to describe processes that break up compounds into particles often involving pressure or heat. Water, for example, can be atomized by pushing it through a small opening or by applying heat and creating steam in which water particles rapidly move past one another. Both of these processes are temporary as water particles, by their very physical nature, will reconnect unless pressure or heat is constantly applied; the force must be dynamic and constant and only then can water particles be suspended or arrested. It seems that water and humans are quite alike in this, but human "nature" differs as it does not have fixed physical properties like water. Human nature is dynamic and constantly redefined by social mechanisms and this property of our nature, the ability for change, is what opens up the possibility for remolding human consciousness or changing human "nature." This suggests that humans subject to docility projects will always have the ability to break from the mold and become any kind of being, including a liberated one. I argue, alongside Walid Daka that social division, or atomization, is a precursor to and is necessary for domination through discipline to be realized. The division of people down to their individual selves, is a particular 
point of a long modular process to produce docile subjects in colonial and capitalist systems. It is a strategy of counter-revolution as it is works to destroy solidarity that would otherwise, or does, exist between exploited and oppressed peoples whether they be workers in the United States or they be colonized Palestinians in the OPT.

\section{Methodology}

In order to explore this topic, I have drawn upon the recent and historical literature concerning the discursive and structural and administrative actions used by Zionists and Israelis to separate, distinguish, and divide themselves from Palestinians and to divide Palestinians from one another. Aside from Walid Daka's work, there is not much explicit scholarly discussion of a discernable and targeted attack on the individual Palestinian consciousness with the intent to produce individual subjects with little to no concern with collective action or unity among Palestinian people in the Occupied Palestinian Territories (OPTs) or across the world. Although this research would best be done through extensive ethnographic work by living in the OPTs and developing relationships with Palestinians in various enclaves to understand their perspective of collective action, revolution, unity with Palestinians across the OPT and externally, and to analyze their communal behaviors and sense of trust or mistrust in the communities. Although enclavisation has possibly created stronger bonds among the people who are trapped within their boundaries, I theorize that it is their consciousness of belonging to a larger Palestinian group and society outside of their local community that allows insight into levels of atomization. 
Historical Background: The Colonization of Palestine

Nestled between the Mediterranean Sea on the west and the Jordan River on the east, Palestine in the past century has been altered politically, discursively, and demographically through Zionist settler-colonialism. The Zionist movement, or Zionism, envisioned the creation of an independent Jewish state that was later determined to be completed in Palestine. Zionism has been an ongoing process to colonize Palestine that solidified in 1947 when the United Nations alongside the crumbling British Empire partitioned the land without the consent of its indigenous Arab population. This politically divided the indigenous heterogenous, or mixed, population of Palestine from the newly arriving European Jewish population. Zionism is argued to be a form of settler-colonialism where colonization primarily focuses on the seizure of lands already occupied by other groups, often eliminating or expelling the former occupants (Elkins and Pedersen 2005). As European-Jewish leaders envisioned a Jewish homeland in Palestine, they were well aware of their mission's colonizing nature. Founder of the Zionist project, Theodor Herzl, in regard to creating a Jewish state in Palestine, wrote in his manifesto, "[I]f I wish to substitute a new building for an old one, I must demolish before I construct," clearly aware of the impending replacement of populations (1902: 38). In order to permanently replace a population, there must be a structure that both expels the former inhabitants and then prevents them from returning. This structure is a constant project and process of dispossession and division that exists as a form of counter-revolution, or in modern terms, counterinsurgency, and is a key component to Israel's continuing colonization of Palestine. The Zionist project can be historically examined in 4 periods that are marked by the 1917 Balfour Declaration, the 1947 UN Partition of Palestine, the 1967 occupation of the West Bank and Gaza by Israel, and finally the contemporary post-Oslo period starting in 1993. Each period consists of different forms and 
levels of division between European Jews and Palestinians that would ultimately culminate into a division amongst themselves by the Zionist state.

At the end of WWI, European powers divided the Ottoman Empire into nation-states based on ostensible "ethnic" and "racial" characteristics of each region with the anticipation that each nation could be ruled by a homogenous people (Robinson 2013: 17). The conflation of race and nation influenced European Jewish writers and leaders such as Herzl to create a distinctly Jewish nation-state. Known as Zionism, this political movement looked to create this state in the newly established British Mandatory Palestine where a small group of indigenous Jews already lived. As anti-Semitism grew in Europe, migration of European Jews to Palestine increased. The Zionist movement was well aware that it had to effectively clear land of its former inhabitants in order to create a "pure" Jewish state. From 1900 to 1947, the Zionist Organization (founded in 1897 in Basel, Switzerland) implemented a colonial strategy that adapted private property laws recognized in Europe as the proper claim to land through the Jewish National Fund. The founding charter prohibited "non-Jews" from leasing, buying, and later working on land that the Fund acquired (ibid.: 17). After decades of dispossession of Palestinian peasants, who were typically evicted because they had no "proper claim" to the land that they worked and lived, the United Nations partitioned Palestine between Jews and Arabs with the support of the British Empire. Subsequently war broke out between Palestinians and the Jewish settlers of the informal Zionist nation known as the Yishuv. Statehood was declared May 14th, 1948. By December of the same year, Jewish forces conquered almost 78 percent of Palestine and expelled over 750,000 Palestinians who became the world's first legally recognized refugees who were forced to leave behind 425 villages and eight cities (ibid.: 27). From 1948 to 1967, Israel would exist in a "state of emergency" in which Jews were entailed full 
rights and protections by the state while the remaining 100,000 Palestinians and those that managed to return in the days following the end of the expulsions were persecuted and criminalized (ibid.: 27).

In 1967, Israel successfully seized the West Bank from Jordan, and Gaza from Egypt, bringing the remainder of Palestine under Israeli control. Meanwhile, in the refugee camps of Lebanon, Palestinian armed resistance movements were organized. From 1967 until the Oslo Accords in 1993 and today, has been marked by colonial expansion into the Palestinian territories through the illegal Israeli "settlements" that are more accurately described as “colonies." The "Master Plan for the Development of Settlements in Judea and Samaria" was drafted by the World Zionist Organization in the 1970s and highlighted the strategic aspects of the project (Drobles 1980). The colonies worked to both demographically alter the Palestinian landscape and to create facts on the ground that maintain Israeli securitization and warrant future annexation of the West Bank. Situated between concentrations of Palestinian populations, the colonies dot the West Bank strategically in order to spatially divide Palestinian communities from one another (Peteet 2017: 6). Over 100 colonies have been constructed in Palestinian territory and over half a million Israeli citizens populate them (ibid.: 5). While the occupation was underway in the OPTs, refugees in the camps of Lebanon were organizing armed resistance, mutual support, and international solidarity with anti-imperialist movements around the world such as those within North Vietnam.

In 1969, Lebanon signed the Cairo Accords which granted Palestinians the right to employment, to form municipal committees in the camps, and to openly engage in armed struggle (Peteet 2005: 7). This enabled the Palestinian Liberation Organization (PLO) and the various groups that composed it such as Fateh and the Popular Front for the Liberation of 
Palestine (PFLP) the autonomy to create state-like entities within Lebanon and provided a solid base of militancy and education. Prominent and influential theorists, intellectuals, activists, and leaders such as George Habash, Leila Khaled, and Ghassan Kanafani came from this period of strong and consistent Palestinian resistance. Their work and ideas gave rise to such texts as "A Strategy for the Liberation of Palestine" written in 1969 and published in Amman that summarized the PFLP's understanding of Zionist colonization of Palestine and the means for liberation in order to create a single, secular, and socialist state for Jews and Palestinians alike. In 1975, after tensions grew within Lebanon between right-Christian militias and the Lebanese army and the leftist Lebanese National Movement, allied with the PLO, a civil war ensued as the state disintegrated. In 1982 Israel invaded Lebanon besieging Beirut and the Palestinian refugee camps of Sabra-Shatila (ibid.: 9). After the massacre in Shatila, the Palestinian armed resistance ended abruptly. The camps were left without physical or economic support and Palestinians living in the OPTs lost their external base of operations.

From 1987 to 1993 a Palestinian campaign of civil disobedience and mass uprisings swept the OPTs. Known as the first intifada (uprising), Palestinians burst into revolt to protest "land confiscations, settlement construction, house demolitions, curfews, and arbitrary arrests and detention, as well as torture and a lack of civil and political rights" (Peteet 2017: 14). In the early 1990s, as the first intifada was coming to an end, the Oslo Accords were being negotiated between the PLO and Israel. The recently established Palestinian Authority (PA) was tasked with limited powers of self-governance and maintenance of security within the OPTs on behalf of Israel (ibid.: 14) Part of the agreement divided the West Bank into three administrative areas: Zone A, under PA control, contains most of the Palestinian urban population; Zone B consists of Palestinian towns and villages where Israel claimed the right to "conduct military incursions in 
the name of security;" and Zone C, which makes up about $60 \%$ of the West Bank, is under full Israeli control (ibid.: 21). Under the auspices of these zones of control, the Israeli state has built an infrastructure of security that consists of walls, checkpoints, and a permit system that significantly interferes with Palestinian mobility and connectivity between communities. Together these produce the archipelago of the OPTs that provide the groundwork of the enclaves that Palestinians are confined to. Palestinian critiques of Oslo argue that the agreements legitimize and enable the continuation of Israeli colonization under the fig-leaf of a peace process. As an example, Peteet writes, "US proposals to initiate Israeli-Palestinian peace talks are often followed by an announcement of the building of new colonies or the expansion of housing units in the West Bank or East Jerusalem" (ibid.: 15). Coinciding with the Oslo Accords, Israel changed its policy to diminish Palestinians as a source of labor by switching to immigrant labor, thus further severing ties between Israel and Palestinians and cutting off essential economic activity for the latter. Palestinians as a captive population are still exploited by the Israeli state due to the post-9/11 security industry boom that Israel has profited from by testing their security technologies on Palestinians trapped in Gaza and the West Bank (ibid.: 15). These poor conditions and high unemployment led to another uprising in 2000 that led to increased closure for Palestinians with a proliferation of checkpoints suffocating the OPTs. Throughout these uprisings and the occupation of Palestine, Israel has heavily relied on carceral punishment that brings us up to the experience of Walid Daka as a political prisoner.

Mass incarceration has been a main tactic of the Israeli state in an attempt to control Palestinian resistance, but this policy unintentionally produced institutions of political education within the prisons and mass-based solidarity structures externally. According to the Palestinian National Authority Ministry of Prisoners' and former Prisoners' Affairs, from 1967 to 2006 
approximately 650,000 Palestinians experienced incarceration. Respective to the Palestinian population in 1967 at 1 million, and 3.8 million in 2006 the incarceration rate has been astronomical. It is rare to find a family who has not experienced incarceration of at least one male member. Research conducted by Maya Rosenfield in 1993 in the Dheisheh refugee camp showed that $47.8 \%$ of men between 25 and 40 had experienced some amount of imprisonment ranging from seven months to fifteen years (2011: 5). During the years of the intifada, imprisonment and administrative detentions ramped up and it was common to find three to four members of the same family in detention simultaneously. Because there was such a high incarceration rate that included many of the OPT's political leaders, prisons became sites of political education and organizing that challenged the Israeli prison order internally and externally (ibid.: 7). The experience of being imprisoned by the Israeli state became an essential part of the socialization and coming of age for Palestinian men. The ethos of the Palestinian prisoner would best be described as revolutionary and this would be transmitted to family members, most often women, who visited them and then returned to their communities where they built solidarity campaigns. Walid Daka experienced this revolutionary time for Palestinian prisoners and then saw its destruction after the Oslo Accords.

With Oslo came the waning of these solidarity organizations and prisoner movements. The depoliticization of prisoner support organizations began as the Palestinian Authority was granted nominal state-building capacities and prisoner exchanges occurred that placed many former Palestinian prisoners in government positions. Whereas before, solidarity campaigns within and external to the prisons were explicitly political and revolutionary, the organizations that replaced them were politically neutral (2011: 15). Daka witnessed the restructuring of the prisons that mark the dissolving of Palestinian solidarity between communities and prisoners and 
the dissolution of the revolutionary nature of prison organizing. The proliferation of NGOs and non-revolutionary government programs for prisoners disengaged the revolutionary capacity of prisoners and their communities in the OPTs. It is within this post-Oslo period that the theorization of atomization comes into fruition; first in the prisons, and then in the OPTs. One of Daka's fellow prisoners succinctly described this remolding, explaining that, "in the past we were one with each other, now we are one against each other" (2011: 240). This breaking apart of people who once were bonded and unified in a shared struggle or experience, is atomization.

The Study of Palestine

Palestine as a site of academic study in mainstream western academics and anthropology has gone through significant changes in the 20th century and was nearly non-existent in the social sciences and anthropology until the 1970s (Furani and Rabinowitz: 2011). From the 19th century to the present, Furani and Rabinowitz write, the study of Palestine has gone through four distinct ethnographic styles: biblical Palestine, Oriental Palestine, absent Palestine, and postructural Palestine. This thesis will analyze Israel and Palestine through the postructural lens that critically unpacks biblical and Oriental analyses that are often deployed to legitimize and support Zionism and Israeli colonization of Palestine.

The first form of analyzing Palestine was the biblical approach that occurred in the 19th and early 20th century. European discourse on Palestine was grounded in biblical studies that analyzed the land and people of Palestine through a biblical lens that was used to legitimize European influence in the Levant and Palestine (2011: 477). This approach objectified Palestinians as living fossils and consequently validated the Zionist claim of "the historic return to a "promised" land (ibid.: 478). Time and space were telescoped as Palestine was directly 
connected to the biblical past, skipping over the thousands of years of change and development that have occurred since.

In the early decades of the 20th century, "scientific" analysis and "logic" replaced theological motives for studying Palestine. The oriental approach replaced the discourse of the heathens and Mohammedans of the biblical scholars with such terms as primitives, races, Orientals, and Arabs in describing Palestine. While continuing to objectify and exotify the people of Palestine oriental scholars examined Palestine through a functional lens that sought to explain how Palestinian society functioned and how the apparent traditional social fabric was being worn away by westernization — the people of Palestine were seen as an assemblage of modern and ancient civilizations (Canaan 1931: 34). This depiction challenged the colonial understanding of Arabs as transient nomads, which not only challenged British justifications of colonization, but contested the Balfour Declaration's endorsement of Palestine as a Jewish homeland (Furani and Rabinowitz 2011: 479). After the creation of Israel and the expulsion of Palestinians, the study of Palestine became marginalized. This period of Palestinian absence in western academia was marked by the development of modern Middle East studies (which excluded Palestinian), the expansion and crystallization of the Israeli state, the spread of Israeli (biblical and oriental) approaches to understanding Arabs and "Israeli-Arabs," and the organization of peasants and refugees into revolutionary parties such as the Palestine Liberation Organization (PLO) in Lebanon (ibid.: 479).

The absence of Palestine and refugees in Middle East studies was only made apparent and addressed starting in the 1980s with the exceptions of Lutffiya (1966), Nakhleh (1975), and Sayigh (1979). Scholars such as Swedenburg (1989,1990), Peteet (2005), Moors (1995), and Said $(1978,1979)$ are some of the exemplary scholars who critiqued the marginalization of the 
Palestinian experience and began to expose the imperialist and colonialist nature of the accepted Israeli/Zionist narrative (Furani and Rabanowitz 2011: 480-481). The work of these writers admitted Palestine and Palestinians as important ethnographic subjects because the case for Palestinians represents a challenge against the justifications and legitimacy of imperialist powers globally. The contradictions, the injustices and the crimes of colonialism, capitalism, and imperialism are rendered visible by the Palestinian experience. This paper begins at the latter half of poststructural discourse working to demystify power relations, challenging national, colonial, and imperial forms of power that emanate from the global north or former and current Western imperial powers.

\section{Literature Review: Atomization in European History}

Evidence of atomization lies in historical European theory of the individual and later crystallizes in nationalism and tactics used by colonizing powers to divide and exploit. These tactics used during colonization would be adopted by the ruling classes of Europe in order to fragment the solidarity of their subject populations in order to usher in capitalism. This review is a look at literature with a focus on division and containment of Palestinian bodies. Afterwards the review will focus on the strategies employed in the colonization of Palestine that can be read for its features of atomization and the fragmenting of Palestine through various divisions and containments.

Max Weber (1864-1920), a theorist who saw the unification of Germany and the growth of his home of Berlin into an industrial metropolis, was concerned with the ways in which industrial capitalism was affecting the new German nation (Patterson 2018: 57). By examining the histories of militaries and armies, Weber connected the discipline used to maintain solidarity 
and structure of army formations to the economic structure of capitalism and the political structure of the state. Weber's discipline(s) is the efficient ordering of subjects by a structure that could be made by heroic leaders (possibly similar to Gramsci's hegemony), despotic slaveholders, a social class, or the actors in a nation-state. Weber goes on to suggest that the technologies and the tools used dictated the form and structure of a given discipline; thus, warriors with spears organized under the use of force discipline differently than workers in factories under the supervision of a foreman. Under the economic discipline of capitalism, Weber says " $[\mathrm{t}]$ he individual is shorn of his natural rhythm as determined by the structure of his organism; his psycho-physical apparatus is attuned to a new rhythm through a methodical specialization of separately functioning muscles, and an optimal economy of forces is established corresponding to the condition of work" (1946[1922]: 261-262). Here domination is hinted at, but not specified or criticized even though Weber is suggesting that capitalism makes bodies and minds into a new form: a machine akin to the factory. Weber's discipline is dynamic and modular, changing in space and time to adapt to various contexts that may include domination or collective consent. These disciplines are not one form of a power structure in a certain time and space like Foucault's but exist at varying degrees that involve a conflict between individual "charisma" and discipline (ibid.: 255).

Foucault's rendering of discipline that exists extensively throughout present discourse and theory is just one of Weber's forms of discipline that is more so influenced by the contributions of Émile Durkheim (1858-1917). Living through a tumultuous period in France, Durkheim was concerned with the means in which society remains stable, unified, and in solidarity. A critical way society defended itself from disorder, according to Durkheim, was through punishment of crimes that work to reify society's norms. These norms are determined by 
his notion of a "collective consciousness" which refers to the shared beliefs, ideas, and moral attitudes of a society. To Durkheim, "modern" society, punished not to inflict suffering on the guilty, but ultimately to establish fear that "may paralyse those who contemplate evil" (1984[1893]: 124). Punishment existed as a means to shape people, to order them into society, to discipline them into the collective consciousness. Durkheim's collective consciousness encompasses the individual in a way that seems to consume all potential agency as punishment works to produce conformity. Durkheim did not account for the possibility of multiple cultures existing in a society who arguably have different collective consciousnesses: this is the reality of Palestine where Israeli society mobilizes to punish or defeat Palestinian society and culture. Israel uses prisons as a means to conduct Durkheim's "restitutive sanctions" against Palestinians who exist as an existential threat to Israeli society. The ability for Israel to remold the Palestinian consciousness is the result of historical injustices of violence, dispossession, and atomization of Palestinians, which relates to the work of Silvia Federici on the violence that preceded the development of capitalism in Europe.

The atomization of Palestinians today is preceded by and continues through processes of colonization by Israeli forces that include violence, dispossession of land, and discursive demonization. These practices share a historical legacy with the development of capitalism in Europe. Engaging with Marx and Foucault, Silvia Federici in Caliban and the Witch shows that structures of power, such as liberal nation-states and capitalism, that exist today to dominate and exploit Palestinians and workers alike, are produced through years of physical and discursive violence against women that we know as the witch hunts. During the crisis of feudalism in the 14th century, fairly egalitarian social and economic relations flourished between peasants and merchants, men and women. In order to accumulate more wealth and land, the ruling classes 
worked to divide the peasantry and working classes by defeating women's power and controlling their bodies. This occurred through the violent enclosing of commons, or shared land, the discursive and physical demonization of women as witches, and the devaluing of domestic labor that was assigned to women. Together this put men and women at economic odds where men were empowered to sell their labor and make wages while women were subjected to devalued domestic labor, effectively enslaving women to their masculine counterparts and to the structures and actors that reproduced this. One major aspect in the reproduction of this system was the control of bodies: the bodies of men were forced to work in the factory to produce value and the bodies of women were tied to domestic labor and forced to reproduce the labor force, the men. Breaking apart the working classes into individuals who are encouraged to compete against one another displaces their power to make effective change, otherwise realized as solidarity. In sum, atomization as a means to discipline is enabled by the processes of colonization that then produces structures and discourses that reproduce domination and discipline. This strategy can be seen in the historical colonization of Palestine and then is highlighted in the post-Oslo years as Israel now has the capacity, the infrastructure, and the wealth to individually fragment Palestinians and decimate their solidarity.

Writing about genocide and settler colonialism, Patrick Wolfe (2006: 388) defined the terms of settler colonialism as a process of elimination and made clear that the invasion of settlers is a structure rather than a single, conclusive event. In order to replace the former population and ensure they do not organize and return to protest their dispossession and exile, a complex system of institutional, physical, and imagined structures is essential. In the case of Israel, the expulsions and structures such as walls and checkpoints have separated most of the exiled population of Palestinians from the Jewish settlers. Furthermore, these structures work to 
unify the settlers while dividing the exiled so that they may never find the strength to return and revolt. But what do these structures look like and how do they simultaneously expel, repel, and divide the exiled community?

Shira Robinson's (2013) work traces the formation of the Israeli state on the land of Palestine by providing a point of departure from which "apartness as structure" came into existence as the means to colonize Palestine and provided a foundation to the structures and discourses that separated Palestinians from Israelis. She examines the legal, physical, and structural means by which Palestinians were expelled or excluded, and the colonial legacy of racializing the colonization of Palestine. The socially produced categories of race that defined European awareness of themselves and others would be the line drawn in the sand between Jews and Arabs in the early 20th century and would be a defining feature of how the world made sense of the "conflict" then and how it is perceived now.

In the early 20th century, race and culture were often used interchangeably with nation and people (ibid.: 17). During this time, nation-building coincided with race-making in European thought and practice that attributed races to nation-states. Conversely, Palestine under the Ottoman Empire hardly exhibited social or institutional recognition of race, ethnicities, or cultural essences (ibid.: 17). As for the various non-Muslim groups, the Ottoman's granted them a large measure of autonomy which fostered fluid relations between Palestinians of various faiths and traditions (Campos 2011). After the European led Sykes-Picot accords carved up the former Ottoman Empire, ethno-religious pluralism became an issue of the state to be solved or removed (Robinson 2013: 17). Thus, under British rule, distinction and apartness were institutionalized in Mandate Palestine. 
Simultaneously, Zionist leaders began to promote "the Jew" as a category of race (ibid.: 18). The envisioned Jewish nation-state would specifically be of the Jewish race at the expense of the formerly heterogeneous communities that composed Palestine. As Zionist leaders were constructing the idea of a Jewish race, the international community assigned the indigenous population of Palestine as a distinct race. The League of Nations declared that the issue of Palestine would be classified between two racial groups: Jews and Arabs (ibid.: 18). As the international community recognized the Jewish race with a claim to a Jewish nation, Zionist leaders and Jewish settlers were affirmed in their mission to create a racially homogenous space for a state. These categories and recognitions of race are the foundations of the borders to be created, citizenships to include or withhold, and the walls to be erected across the Palestinian landscape.

In her work, Shira Robinson (ibid.: 26-27) examines the foundations of apartness that defined early Israeli settler-colonialism by revisiting Zionist leaders' plans to replace the Palestinian population. In the period between 1948 and 1966, Israeli governance of Palestinians would be defined by martial law and Emergency Acts adopted from the British as a means to override legislative processes (ibid.: 33-35.) The military policy that defined the first year of Israeli military rule, known in Hebrew as tihur, or literally purification, underwrote the mass expulsion and massacre of Palestinians resulting in nearly 85 percent of Palestinians cleared from the Israeli occupied land (ibid.: 26-27). Born in a frenzy of ethnic cleansing, the Israeli state would crystalize Jewish space through military rule until 1966. However, the complete colonization of Palestine envisioned by the Zionist project as from the river Jordan to the Mediterranean Sea was unsuccessful. In spite of the 1967 occupation of the West Bank and Gaza Strip (OPTs) many Palestinians remained steadfast on their land and in their homes. By merely 
staying put they created a dilemma for Israel. To annex the land meant incorporating Palestinians into the state, altering the demographic reality and threatening the "Jewish character" of Israel. To expel or massacre the remaining Palestinians would possibly position Israel as an international pariah, destroying its crucial alliances with Western nations. Thus, the nature of conquest was altered, and the settler-colonial dilemma of demographics exposed.

The starting point for the physical and discursive separation of Palestinians from each other begins with the period after the 1948 war when Palestinians sought refuge in neighboring Arab countries. And it was furthered in 1967 when Israel officially occupied the West Bank and Gaza. Eyal Weizman's (2007: 70) work analyzes Ariel Sharon's regime during this period that is marked by a transition from pure expulsion to division and immiseration. Sharon's regime devised and implemented the militarized division of refugee camps in Gaza in order to break the unity of Palestinian resistance movements that bloomed in the camps. In addition, the construction of settlements in the West Bank and Gaza, under both the Labor and Likud parties, was a means to begin demographically altering the Palestinian landscape; to create facts on the ground that would complicate future peace agreements if a Palestinian state were recognized and would ultimately splice the remaining Palestinian communities (ibid.: 81). The invasion of the occupied territories also saw the creation of permanent and temporary checkpoints that served to bottleneck and monitor the movement of Palestinians in the newly envisioned enclaves (ibid.: 149). Laleh Khalili adds to this by arguing that both the encirclement of Palestinian communities by settlements and the mass incarceration of Palestinians were projects of social engineering to craft the occupied Palestinians into disciplined subjects that ultimately "securitizes all forms of social solidarity" (2013: 210). Her analysis of the structures described by Weizman illustrates a 
pattern of divide and rule that splits Palestinians as a means to not only control them, but to alter them.

The evidence of separation and segregation in the past three decades is apparent through Julie Peteet's exploration of the complex and chaotic system of walls, checkpoints, and permits that now defines the Palestinian landscape. After the first intifada, Israel enacted a policy of closure in the OPTs that has led to "fragmentation, economic devastation, social fracturing, and a deep sense of isolation and abandonment" (Peteet 2017: 10). This contemporary period is marked by the mass-incarceration of Palestinians, advanced surveillance and policing, Palestinian displacement and urbanization due to land expropriations and the closure of agricultural lands, the expansion of settlements across the OPT, and the crystallization of the enclaves (ibid.: 10-11). The formation of enclaves, settlements, by-pass roads and checkpoints, and their recent solidification and encroachment, has structurally and discursively engineered the OPT as an archipelago of separated communities.

It is through the myriad of structures and institutions that segregate Palestinians alongside a history of discursive constructions of apartness that Walid Daka's theory of discipline, by way of Michel Foucault, comes to fruition. From his personal experience as a Palestinian political prisoner and his own research on Israeli political leaders and military strategy, Daka has theorized that Israel's goal to complete the annexation of the OPT will be achieved through a process of consciousness molding that will ultimately shatter the collective values of the Palestinian people (2011: 237). This consciousness molding refers to Foucault's notion of discipline in which political bodies are made docile subjects (1984 [1975]: 189-202). Daka observes that prisons serve as laboratories in which policies are tested and then implemented 
upon the Palestinian people and this includes the reconfiguration of Palestinian consciousness on the individual level (ibid.: 237-238).

Daka describes the Oslo Accords as the beginning of the end of the Palestinian struggle and the introduction of atomization as the final solution. The Oslo Accords replaced the Palestinian revolution with the Palestinian National Authority (PA) and changed the discourse and movement from a liberation struggle to a legal battle; the fight against corruption becoming the political discourse of Palestinians (ibid.: 238). Inside the prisons, political leaders that once organized and led movements outside were isolated, confined, and separated from one another until the organizations that they once communicated with were eliminated or subsumed by the PA where they lost their capacity as a revolutionary force (ibid.: 239).

\section{Conclusion}

Marx, Weber, and Durkheim were writing about and engaging with structures and networks of power and domination, that were the results of these initial accumulations and dispossessions. Their successors, specifically Foucault through Durkheim and Federici through Marx, write about and engage with contemporary networks of power and domination that stem from these conditions of the past: Europe's colonizing of the world (and enslavement of "the primitives") and the birth of nationalism and industrial capitalism. The history of atomization is the history of colonization, nation-state building, and capitalist development; it is the history of the working classes, women, and Palestinians. To be atomized and disciplined is the result of these histories and the result of the ongoing reproduction of systems of domination and exploitation. The struggles of these groups are thus linked. Walid Daka's imprisonment, the witch hunts of 15 th to 17 th centuries in Europe, and the impoverishment and suffering of the 
workers of the world are connected. Any means to end colonialism, capitalism, and patriarchy must be done collectively as a unified project.

The continued colonization of Palestine is directly linked to the oppression and exploitation of the world's working class - atomization, or the breaking apart of people, smashes solidarity, pitting us against one another, instilling distrust and division, while pretending to unify us under banners of "the nation." This is the strategy of the ruling class, the bourgeoisie, the capitalists, in pursuit of their project of unrelenting wealth accumulation. The breaking of solidarity, from resistance to revolution, has never ended. Atomization has been the strategy to quell the constant struggle that the ruling class is met with as workers and the oppressed encounter capitalism's contradictions and paradoxes. 


\section{CHAPTER 2: APARTNESS AS STRUCTURE THROUGH DISCOURSE AND ACTION}

This chapter outlines the context in which human apartness was developed over the centuries in European thought, and how these concepts took shape in Zionist thinking and unfolded in the colonization of Palestine. The divisions imagined and enacted between Palestinians and Israelis were part of larger historical phenomenon linked to European concepts of the self and society that posited cultural superiority - beginning in the 16th century and crystallizing in the 19th century with the advent of race science, anthropology, and made 'facts on the ground' that were the colonization of the world by Europe. Concepts such as civilization, primitive, orient, and progress, would inform arguments that justified and supported the colonization of the world by Europe and the prominent settler colonial projects of the United States, Australia, South Africa, and Israel. It was the circulation and wide acceptance of this understanding of the world and its people that made such brutal regimes of colonialism and the genocides of settler colonialism possible.

Dean Itsuji Saranillio speaking on Patrick Wolfe's (2006) definition of settler colonialism as a formation of colonial power that seeks to replace current inhabitants with settlers, adds that this system "requires an obstinate kind of ideological productivity" that "...necessitates a discursive regime - underpinned by juridical and military force - that is productive of normalizing occupation and making sense of the genocide that this kind of replacement requires" (2015: 284). Discourse and violence converge in an "antiprimitive logic" to justify settler colonialism (ibid.: 284). This relates to Andrea Smith's theorization of white supremacy where interrelated logics of labor exploitation (capitalism), genocide (settler colonialism), and war 
(orientalism) work to analyze race and racial formations that were and are key to colonial projects (2012: 66). Most pertinent to this chapter are the logics of genocide, which anchors settler colonialism through the disappearing of the indigenous, opening territorial claim to settlers, and of orientalism, which "marks certain peoples or nations as inferior and deems them to be a constant threat to the well-being of empire" (ibid.: 69). Woven together, colonialism imaged Palestine as a place devoid of Arabs and thus open for settlement and state-building while orientalism as accepted discourse justified the initial and continuous violence against them.

The production and circulation of Zionist discourse in the early 20 th century functioned to rationalize settler colonialism by attempting to erase the indigenous past and present and replace it with a new historical narrative that supported the supposed indigeneity of the settler. Palestinians, being the indigenous people of Palestine, must not only have been removed from the land, but erased from history. Palestine had to be remade in a Zionist image, replacing one landscape for another. This would occur through the circulation of texts and media such as Edidin's primer, the film Avodah (labor), and importantly, maps. Together this media ensemble would attempt to destroy the historical landscape and dilute the memory of Palestine before the nakba and create an imagined place inhabited in the ancient past and in the near future, both exclusively Jewish. These narratives of primitives and Orientals, savages and barbarians, are not unique to the Zionist movement; their leaders and theorists were informed by centuries of European thought.

"Civilization" and the "Primitive"

Between the fifteenth and eighteenth centuries, Western Europe saw the expansion of global empire, a burgeoning discourse of new formulations of governance that turned away from 
monarchy and divine-rule, technological and scientific developments, and rapid changes in production and economic relations that generated industrial capitalism (Patterson 2018:21). Influential writers who found themselves benefiting from Europe's dominant position in the world framed the changes taking place across time as "progress" (ibid.: 21). Change through time was positioned as a unilineal process in which the only way through was "up." This linear projection positioned Europeans at the height of progress because they possessed civilization, coined in the 18th century. Louis Le Roy (1510-1577), advisor to the King of France, wrote that humans advanced from a primitive form to a more advanced one (see: European) in stages through intellectual, moral, and social "progress" (ibid.: 23). In describing the process, Le Roy used the verb civiliser (to civilize), and in this formulation Europeans found a justification, more so a moral duty, for their global domination of other societies. José de Acosta (1540-1600), employed by the King of Spain, designed a system of classification for non-Christian societies based on their capacity to be civilized (ibid.: 22). Literate non-Christians could be taught of their backwards ways, illiterate barbarians could be swayed to the faith with a strong ruler and a settled lifestyle, but savages who lacked laws, literacy, and governing structures could only be civilized through force (ibid.: 22). To address how Europeans advanced through the stages “naturally,” philosophers Francis Bacon (1561-1626) and René Descartes (1596-1650) argued that through reason society improved and progressed while on the other hand, a lack of reason explained the "backwards" and "static" societies of primitive people (ibid.: 24). Thus, in the European formulation of world societies, Western Europe, possessing rationality and subsequently civilization, was viewed as superior. Those who benefitted from the global exploitation of other people's land and labor believed they were doing the Lord's work by bringing "civilization" to the "primitive". 
Although the discourse of the primitive prevailed in the centuries to come, a myriad of writers took issue with the formulations of Acosta and Le Roy. One of their contemporaries, Michel de Montaigne (1533-1592) complicated the discourse of the primitive by casting light on the cruel and vicious actions of so-called civilized society (Patterson 2013: 25). Montaigne was aware of the dichotomy pitting civilization against the primitive being mobilized as a justification to engage in their own barbaric actions. Similarly, Giambattista Vico (1688-1744) critiqued the notion that European society was the product of a rational nature, and instead wrote that social institutions and modern society were part of long historical processes that either fostered intellectual advancement or eroded it (ibid.: 27). Aware that humans were diverse socially, economically, and politically in particular historical arrangements, Vico challenged the notion that Europeans were naturally more advanced.

Jumping forward to the late 19th century in the United States, anthropologist Franz Boas (1858-1942) and sociologist W.E.B. Du Bois (1868-1963) argued that the social and economic positions that were tied to race, class, and language were due to historical processes, rather than an innate and static human nature (ibid.: 90). Thus, black folks in the United States were not poor because of a supposed natural inferiority or innate disposition, but because they were subjugated through a long history of economic exploitation realized in the state-sanctioned system of slavery, and subsequent institutionalized policies and practices of economic exclusion. It was through violence and domination, made justifiable by the long discourse of white supremacy, that black people in the United States lived in significantly worse conditions than their white counterparts. Boas' work challenged the long-held notion of unilineal evolution, that posits humanity has evolved in a linear fashion. In "The Methods of Ethnology," he wrote "that each cultural group has its own unique history" dependent on its particular internal social organization 
and on external influences (1920: 317). Therefore, perceived hierarchies and notions of racial superiority were fabrications of European thought maturing over years of brutal acts of violence, pillaging, and land seizure against other peoples. The emergence and solidification of an "us" and "them" view of the world (us being the civilized and them being the primitive) would translate on the ground into the political organization of states in Europe and around the world with the spread of nationalism and the conception of the "nation."

\section{The Nation}

In European thought, conceptions of "the nation" and "the citizen" were historically used to unite groups and exclude others within and external to localities determined by their governing bodies, or states - a discursive force that eventually would be mobilized to justify and frame the settler colonialism of Zionism. During the late 19th century and up until the 20th, nation-states and national identities were crystallizing across the Western world (states with industrial capitalism) such as in Germany, Italy, and the United States (Patterson 2018: 71). These consolidations were the result of a long historical discourse concerning the definition and nature of a nation and the relationship of the government to the people it held sovereignty over. Earlier writers such as Immanuel Kant (1724-1804) posited that a nation should be a bureaucratic structure that encompasses its various cultural and linguistic groups. Others, such as Prussian philosopher Johann G. Herder (1744-1803), argued that the nation was defined by its cultural and linguistic elements in a set geographical space (ibid.: 86). Herder posited that a nation was composed of a people who shared the same language and held similar patterns of thought, such as shared symbols, rituals, and traditions (ibid: 86). Thus, a nation was either a "republic," a state that guaranteed rights to individuals and created a unified group (national identity) through 
political and cultural means, or an innate entity born from the social and cultural connections of a particular group. Later European writers such as Max Weber (1864-1920), who saw the unification of Germany and the growth of his home city, Berlin, into an industrial metropolis, was concerned with the ways in which industrial capitalism, an economic system in which land, equipment, and labor used to produce goods and services is privately held by a small group of people (bourgeoisie; capitalists) whereas the rest of society earns wages working for this class (proletariat, working class), was affecting the new German nation (ibid:. 57). In 1895, he wrote that the nation was a result of the organization of the ruling classes and their political and economic systems that defined national subjects and provided a material solidarity that distinguished them from other national groups, referring to Kant's republic of individuals granted rights but in the new context of contemporary industrial capitalism. (ibid.: 90).

These notions of "the nation" theorize either a unified social group determined by its rulers or an innately produced group defined by its ethnic and linguistic characteristics. They depict a world that should be instead of critically examining the material reality of people living in these states deemed nations. Merging Herder and Kant and examining Germany as the German people, unified by language and culture under a single polity, depicts a static world of finite cultures fixed in space and fails to account for exploitation, oppression, and marginalization of minorities. Furthermore, it obfuscates the distinction between the ruling class capitalists and the subordinate class of workers by producing an illusion of unity: both the exploiter and exploited are German, a recourse to ethnicity to enhance unity and gloss over exploitation and common class interests. These ideal theories of the nation and state influenced the future of colonialism wherein European powers would dictate the political and economic fates of foreign societies. 
The rapid expansion of capitalist states and their economies in Europe eventually led to conflict about deciding how the "primitive" world would be divided up, resulting in World War I. Afterwards, European powers, most prominently the French and the British, drafted the SykesPicot Treaty. This treaty divided the Ottoman Empire into British and French Mandates and attempted to form them into their own image-one derived from assumptions of ethnic-religious hegemony, or the rule of a specific ethnic group. In Europe this played out as Weber observed, Kant mystified, and Herder believed that the "western nation," as a republic, democracy, or monarchy, would always be ruled by a specific class and that culture would define it.

Providing a more compelling theory of the nation than Kant's sterile theory of the republic, Karl Kautsky (1854-1938), a theoretician in the Social Democratic Party concerned with the working class, wrote that the nation-state emerged as a result of capitalists' demand to reorganize the polity to accommodate or articulate a capitalist economic model. The rulers of these new nation-states would be capitalists, or the class who owns private property and capital, instead of the previous ruling aristocrats. Karl Marx (1818-1883), concerned with the expansion of industrial capitalism and its effects on society and specifically workers, described the process in which owners of industry, or capitalists, accumulate wealth by exploiting the labor of the working class (1976[1867]). In his most circulated work, The Communist Manifesto, Marx writes that the modern nation-state is merely an apparatus for the workings of the ruling class and capitalism (Patterson 2013:72). Thus, as argued by Marx, the nation-state is not merely a governing structure that protects individual rights, but it is a structure that enforces domination and exploitation through capitalism.

Having laid out the context for the emergence of the nation-state, we can return to the dilemma that has plagued Zionism from its early formation to the present: how can you have a 
democratic Jewish state in a majority non-Jewish place? Early Zionist organizations, leaders such as Theodore Herzl and David Ben-Gurion and their religious communities in Europe found themselves excluded from the protection of the state and society while facing rampant and rising anti-Semitism in the late 19th and early $20_{\text {th }}$ centuries. Zionists adopted the notions developed and utilized by western powers of the nation, nationality, citizenship, and individual rights to launch the formation of a state that would culminate in the large-scale exclusion of Palestinians which continues to this day. The Zionist movement was well aware that it had to effectively clear land of its former inhabitants in order to create a "pure" Jewish state, a policy that was not unlike Europe's facilitation of mass exchanges between Greece and Turkey in what British Foreign Secretary Lord Curzon called "ethnic unmixing" (Robinson 2013: 12). Demographics would continue to be a critical issue for Zionism as it is for all settler colonial projects. From 1900 to 1947, the Zionist Organization (founded in 1897 in Basel, Switzerland) implemented a colonial strategy in Palestine that adapted European notions and laws of private property as the proper channel to claim land through the Jewish National Fund (ibid.: 12). The founding charter prohibited "non-Jews" from leasing, buying, and later working on land that the Fund acquired (ibid.: 12). After decades of Palestinian peasant dispossession, typically evicted because they had no "proper claim" to the land they worked and lived on, the Zionist movement embraced the idea that the creation of the Jewish state would require a mass removal of Palestinians that became known as Plan Dalat (see Walid Khalidi 1988). War broke out following the United Nations' 1947 decision to partition Palestine between Jews and Arabs, an internationally backed approval of Zionist colonization. The Haganah, the military branch of the Yishuv (the Jewish community in Palestine), "instructed field officers to destroy and depopulate (in Hebrew, tihur, or purification) any village whose residents resisted conquest" while offering no measures if a 
village were to surrender (Robinson 2013: 26). By December 1948, Jewish forces had conquered almost 78 percent of Palestine and expelled over 750,000 Palestinians who would become the world's first legally recognized refugees (ibid.: 27). These actions, which dispossessed the majority of the Palestinian population, were justified by the "national cause" that united the Jewish nation and by the initial claim that European Jews were bringing civilization to the backwards people of Palestine. The discourse of the primitive led to a mass accumulation by dispossession that then provided the implied necessity for settlement; in fact, the land was now empty of its people. The newly independent state of Israel declared itself a "democratic republic" and simultaneously the "national home for Jewish people" (ibid.: 28). From 1948 to 1966, the state of Israel enacted a "state of emergency" in which Jews were entailed full rights and protections by the state while the approximately 100,000 Palestinians who remained were governed by discriminatory and restrictive military laws. By effectively utilizing discourse that permeated Europe concerning the development of nation-states and the position of Europeans as the epitome of civilized society, the Zionist mission was enacted with the European legal system and racialized moral compass.

In a 1915 speech reminiscent of the civilizing discourse of centuries past, a young activist of the social democratic Jewish Workers' Party named David Ben-Gurion spoke before an audience of potential Jewish immigrants to Palestine in New York with this message: the Yishuv needed more recruits to fight "wild nature and wilder redskins" (ibid.: 13). The imagery of the United States' conquest over the "savage" natives was used to draw interest and to inspire immigration to the "frontier" that was Palestine. David Ben-Gurion would go on to become one of the founders of Israel and it first Prime Minister. Ben-Gurion was shaped by a period of crisis in Europe, especially for the various Jewish communities. The Zionist movement built its 
foundational argument on the ideas of Europe's intellectuals of the 15th and 16th centuries, portraying Palestinians as an inferior and primitive culture (ibid.: 13). Palestine would become a Mandate, or colony, administered by the British because Arabs were "not able to stand by themselves under the strenuous conditions of the modern world" and in the hopes that their British overlords could teach them how to govern themselves (ibid.: 14). Zionists petitioned British administrators to cede administrative control of the territory to the Yishuv because it was their mission to bring "prosperity and civilization to the backward peoples of the Holy Land" (ibid.: 15). For the Zionist movement and the Yishuv, demographics and questions of the nature of democracy and citizenship became issues as the movement grew closer to attaining a state in Palestine. The words of David Ben-Gurion were few among a vast sea of propaganda and discourse that posited Palestine as the new frontier for the Jewish homeland. Media would be the vector of Zionist, settler colonial, and racist ideas that would circulate amongst European Jews and their diaspora during the pre-state period leading up to the nakba.

Evidence of Discursive Division Pre-State: Books, Films, and Maps

Through Zionist discursivity and colonial actions in the early 20th century, Palestine was gradually remade — demographically, legally, politically, and socially — into a Jewish-exclusive embryonic state and society. This subsequent consciousness of Palestine as Jewish was used to justify and frame a settler-colonial national endeavor. A socially produced narrative, body of knowledge, and consciousness among European Jews, and eventually including American Jews, shaped their temporal and spatial understanding of the land and the people of Palestine. This powerful narrative has been difficult to dislodge from the present American and Israeli consciousness because a complex global machinery of silencing maintains an almost exclusive 
control over the historical narrative of Palestine. From the peasantry to urban dwellers, the merchants and literati, Palestinians as a whole were imagined and essentialized as primitives. In the villages they were agriculturally backward, if not destructive, and in the cities were seen to promote exploitative mercantile practices. The demonization of the indigenous population and characterization of their relationship with the land as destructive and exploitative was used as one among many means to justify the settler-colonization in Palestine in pursuit of a Jewish state. The Zionist narrative and imagination of Palestine circulated through various forms of media that repeated and affirmed these characterizations. This section will explore various media such as books, film, and maps used to perpetuate these conceptions of Palestinians and the land of Palestine, the character of the portrayals, and the social nature of concepts that defined this process such as nationalism, colonialism, and racism.

In the decades leading up to the creation of Israel and the expulsion of Palestinians in 1948, a genre of books was written to educate Jewish settlers and youth about the land and people of Palestine. A primary example of such early Zionist educational material is Ben Edidin's Rebuilding Palestine (1939) penned by an educator working in Tel Aviv schools as a principal. This primer targeted Israeli youth and newly arrived settlers in Palestine (ibid.: vii). Edidin opens with a request that this book be in all educational facilities and public institutions and that every Jewish household should have a copy within arm's reach (ibid.: viii). With any of these primary sources of media, there is a question of distribution - how many homes and schools actually used this book? The total number printed, purchased, and circulated is unknown (similar to the film cited later in this chapter). Instead I can only assume their use. Being an experienced educator and a principal in the largest Jewish settlement at the time, Edidin must 
have commanded some amount of authority and respect. And with that authority, Edidin produced and spread an image of Palestine as a barren and desolate landscape.

Edidin's primer utilizes discursive characteristics of settler colonialism which involve describing the land in question as barren and the people as either being absent, savage, or primitive; and that the land is not being used to its full potential by its inhabitants (Gatseyer and Flora 2000: 128). These rhetorical techniques displace the indigenous population discursively with the effect of influencing the judgement and actions of current and future settlers. The Zionist mission then seems a noble pursuit, both enhancing the land and bringing civilization to the primitives. Throughout the book - in what seems like every other sentence-Edidin emphatically describes how barren the land is and how it was made this way by the "primitive" techniques of the Arab peasant farmers (1939: 2, 16, 33, 66, 67, 130, 215). These peasant farmers are described by Edidin as a backwards people who live in unfurnished mud huts, sometimes with their animals when the climate is harsh, and to whom "cleanliness is hardly known" (ibid.: 215). As for the urban Arab, Edidin wrote that there existed no modern cities in Palestine; the cities that did exist were crowded, dirty, and lacking modern manufacturing (ibid.: 49). In contrast, the newly created Jewish city of Tel Aviv apparently inspired envy in the Palestinians as the "most cultured city" in the region (ibid.: 49). Edidin makes it a point to say that while the Arabs were at a standstill, Europeans were progressive and forward thinking, and making advancements in technology (ibid.: 62). The produced and circulated image of the primitive Palestinian, starving their soil and neglecting their cities, primed them as a population not worthy of the land, a common colonial refrain.

Beyond discursive characteristics of colonialism, Edidin enthusiastically argues for the Jewish colonization of Palestine and makes claims to the land by utilizing European theories of 
nationalism and supremacy. Furthermore, in eliciting a powerful call to action in a time of widespread anti-Semitism and ethnic-conflict, Edidin stressed that the rebuilding of the Jewish nation was essential to Jewish survival (ibid.: 1). He explicitly commends European colonialism boasting about their "discovery" of three new continents with "uninhabited" land that were “opened" for settlement (ibid.: 91). In fact, these continents were not first discovered by Europeans and furthermore were falsely described as mostly uninhabited. Those that did inhabit these "new" lands were an inferior people; thus, the land was open for appropriation and settlement. The indigenous were made available for erasure and replacement. Edidin's support of colonization comes to no surprise since the white supremacist discourse of the Europeans that justified their own brutal acts across the world informs the ideology and literature of Zionism. Not only did Edidin and Zionist discourse draw a picture of a civilized European Jewish people versus a primitive Arab population, but they distorted time in order to crystallize a relationship between the Jewish people and the land of Palestine.

Edidin's and the Zionist claim to Palestine was convincingly argued by collapsing time and space in order to create a land that essentially required the presence of the Jewish people for its regeneration. To Edidin this need comes from a sacred bond between the land and Jewish people that, to him, inspired the ancient people of the Kingdom of Judah to follow the one God of the Jews, Yahweh (ibid.: 93). After the dispersal of the Hebrew people, the thousands of years between ancient Israel and the contemporary conquest of Palestine becomes history — everything existing between these two epochs deemed unworthy of mention, to be forgotten and destroyed. Edidin writes that the time of ancient Israel knew the greatest achievements and since the demise of the Jewish state, "the land was of complete darkness - neglected and desolate" (ibid.: 98). He goes on to conclude that the Jewish claim to Palestine is based on their historical achievement on 
the land and that Arabs produced nothing of lasting value (ibid.: 98). Subsequently, the existence of different civilizations in Palestine over the many centuries was ignored and expunged. The few mentions of the Romans, Arab Muslims, and Ottomans are all positioned as degenerative occupations. The return of the land to the Jewish people is a mission of civilization, ending a long period of wasting (1939: 111-112). Edidin's image of Palestine as a land redeemed by the Jewish people can be seen in the medium of Zionist films being produced around the time of his book's printing.

Written and directed by Helmar Lerski, the film Avodah (1935), "Labor" in English, is a silent documentary of the pioneering labor of early Jewish settlers in developing Tel Aviv and farming settlements known as kibbutzim. The opening scene follows a white man dressed in western clothing walking swiftly through an arid landscape, advancing in an unknown direction until the camera pans as he grins and looks over the valleys of Palestine; depending on the audience, this white man is either a pioneer or a colonizer. His continued march includes views of empty villages and a couple of Arabs herding sheep. After he reaches the kibbutz the film switches to scenes depicting Arabs laboring in various industries: some working in the fields harvesting wheat; some running an animal-powered mill; while others are seen using an old well to bring up a pail of murky water. This scene appears at first to honor the labor of the Arab peasantry but as the score changes from somber to elevated, the film shifts gear; the music and action on screen accelerates.

The scenes that follow and make up the body of the film include title screens such as "Development," "Road Building in Tel Aviv," "Building in the Colony," "Drilling for Water," and "The Pump," that depict white people in action, developing the land and building infrastructure in the kibbutz and in Tel Aviv, marked specifically by their technological 
advancement and speed. A row of white men hammering is shown, a plow swiftly being pulled by a tractor, then the words: "since thousands of years the plough sinks into the ground again!" Transitioning from masculine imagery and music is a serene scene of white women and children planting seeds in a patch of barren earth. As Edidin would say, this will make the desert bloom. The score picks up again and men with heavy machinery are seen laying roads. Then on the completed roads, cars whiz back and forth, something that the Palestinians, only ever seen riding donkeys or on foot, seem to lack. Following this scene of road building an illustrated map of Tel Aviv appears, described as a Jewish suburb of Jaffa. While the map only depicts a dot for the city of Jaffa and a few streets for Tel Aviv; these lines that represent streets begin to expand rapidly, engulfing the land. The rest of the film follows white men drilling for water in an abandoned well. At first their manual techniques fail, but when engines are introduced to drill and pump, the well erupts with water and the colonizers celebrate with dancing and the drinking of wine. The final scenes are of abundant crops; the camera follows a group of marching white people as they sing, ending with the camera zooming into a waving Zionist flag.

The shift in content and score contrasts the primitive technologies and methods of the Arab peasantry and highlights the European's modern technology and rapid development of the land, fitting neatly into Edidin's depiction of the backwards Arab, the progressive Europeans, and the Jewish redemption of Palestine. Palestine is depicted as a barren landscape only until the advanced technology of the European makes the land fertile and rich. Europeans and Americans who watched this film likely saw a familiar image of an "uninhabited" land open for settlement that bursts with productivity through the use of western technologies. The scene of an expanding Tel Aviv illustrated a critical aspect of colonialism and empire: map-making. 
In an effort to understand the Arab Palestine that was refashioned into a Jewish Palestine through conflict and forced migration, writer and former mayor of Jerusalem, Meron Benvenisti writes about his father's legacy as a Hebrew cartographer. As a child, Benvenisti traveled across Palestine with his father learning about the landscape and the people who lived there, only realizing many years later the role his father played in emptying this landscape of its inhabitants and erasing the names of their villages, valleys, and hills. In the first paragraph of his book, Benvenisti (2000: 1) illuminates the trajectory of his book and shares his understanding of the power and purpose of maps in the colonial project:

\begin{abstract}
This book is about my troubled internal landscape as much as it about the tortured landscape of my homeland. "Landscape is the work of the mind," writes Simon Schama. "Its scenery is built up as much from strata of memory as from layers of rock." As long as I can remember myself, I have moved within two strata of consciousness, wandering in a landscape that, instead of having three spatial dimensions, had six: a three-dimensional Jewish space underlain by an equally three-dimensional Arab space. My late father, a geographer and mapmaker, was responsible, unwittingly, for this dual image and split consciousness. From a very early age I was taken along on his expeditions and on his visits to Arab friends. So the Arab landscape was never alien or threatening to me; on the contrary, it gave rise to images, smells, and a sense of human warmth so powerful that their mark has not been erased after half a century.
\end{abstract}

For the child Benvenisti, Palestine was a place of two distinct peoples that made up a single landscape. It was in his coming of age that he discovered the reasons his neighbors disappeared, why the villages he visited in his childhood were left empty, and the Palestine he once knew was quickly becoming homogeneously Jewish.

The history of British mapmaking has its roots as a technology of war and settler colonialism. The first official maps produced by Great Britain were of Ireland. In 1653, the British sought to confiscate land from the Irish who refused to become subjects of the British crown, finally parceling it out to English soldiers and settlers (Benvinisti 2000: 15). In short, mapmakers were at the forefront of Britain's imperial expansion, walking alongside and even in front of the British officer (ibid.: 15). Maps and geopolitical strategies are a prominent connection between the British Empire and Zionist colonialism: "[I]t is no coincidence that the 
1:125,000 scale map that served as the basis for the work of the Israeli $\mathrm{NNC}_{1}$ had been prepared by two of the most famous figures in the annals of the British Empire, Herbert Horatio Kitchener and T.E. Lawrence (Lawrence of Arabia)" (ibid.: 15). Britain's interest in the region was to control the Suez Canal and secure the region for their own economic and political interests (ibid.: 15). Thus, the importance of mapmaking in the region as a military and imperialist project of colonizers will play out once again in the Jewish conquest of Palestine.

With the end of the British Mandate of Palestine, the same Jewish committee that served the British administration would merge into the Jewish National Fund's (JNF) Naming Committee and take up the former's mission to transliterate the Arabic place and topographic names to English and to change the names from Arabic to Hebrew and Biblical names (Benvinisti 2000: 25). The Naming Committee's maps were mandated by the new Israeli state to be the official maps of Israel and to be utilized by all public institutions (ibid.: 25). This evidence makes clear that the circulation of these maps at the dawn of the Israeli state saturated literate society, whereas the Hebrew names of places and landscapes would spread even throughout the illiterate. After the expulsions and massacres of Palestinians from their homes of 1948 and the denial of the right of return, the mapmakers of the Naming Committee would work to erase the name of villages cleansed of their residents and would rewrite the names of historic sites and physical features of the landscape in Hebrew. Physical renaming became necessary as the maps used by early settlers and colonizers were produced by the British and these maps detailed the many Arab villages that Israel had either leveled (the destroyed villages were marked as "heaps" or "ruins") or emptied. In other words, the scars of Israeli colonialism had to be officially erased (ibid.: 41).

1 The Negev Naming Committee was formed in 1949 by Israeli Prime Minister David Ben-Gurion as an emergency committee to assign Hebrew names to all the geographical places of the Negev (Benvinisti 2000: 12). 
The books and maps that would be published reflecting these changes would simultaneously alter and confirm the Jewish community's consciousness of Palestinian place. Benvinisti's father published a book entitled Our Land that confirms the Naming Committee's maps and Edidin's writings of the landscape of Palestine and the Arabs residing there. Benvinisti senior describes the Arabs as a primitive people who had let the land go to waste asserting that the Hebrew people would revitalize the land back to its ostensibly former Jewish glory (ibid.: 5859). It is in these writings and maps that the subsequent configuration of Jewish consciousness of Palestine was formed and where Benvinisti Jr. finds conflict within himself: a child that knew Palestine as a place of two peoples with distinct features that were both human and warm, and an adult who watched himself and his family participate in the uprooting and erasure of Arabs in Palestine beginning with the very process that gave him this consciousness: mapmaking.

In terms of discursive creations, Edidin portrays Palestinians as "primitive" and "backwards," and describes the land as fertile for Jews and barren for Palestinians. Avodah tells the same story: a barren land with a "primitive" population that can and will be transformed and made productive through the advancements of European technology. The maps crafted by Benvinisti's father marked the land as Jewish, as Hebrew, with little to no trace of the indigenous people and the Arabic language. The language and methods used by these "pioneers" fit into a genre of European thought that, although is not inherent to a specific time and place or people, discerns humans into groups of varying worth, ability, and human-ness. The Euro-Christian cosmology of the Great Chain of Being plots human history on a teleological line beginning with savagery, then barbarism, and finally, civilization (Kuper 2005: 29). The word civilization itself was not coined until the mid-18th century by Europeans to describe themselves using terms like progressive and modern and to describe people who did not have the same social structures or act 
in similar ways as themselves as primitive, or lacking civilization, and savage (ibid.: 29). In this framework, primitive peoples were stuck in the past on the Great Chain of Being and consequently were lesser beings. If we were to ask Edidin, Benvinisti Sr., and Helmar Lerski if they thought Palestinians had civilization, progress, or reason, it could be assumed that their answers would resonate with the racist discourse of "civilized" Europeans versus the "primitive" others. These discursive creations of division work to justify violence against Palestinians and the appropriation of their lands. In terms of atomization, these creations provide the necessary framework and grounds to divide colonized bodies from the settlers, and from one another. The art of division is the breaking of bonds and a counter-insurgency strategy to combat the solidarity and possible liberation of the oppressed from the occupation of settler colonial systems 


\section{CHAPTER 3: COLONIZING LAND, BODIES, AND SOULS: ISRAEL'S ATOMIZATION OF PALESTINE AND PALESTINIANS}

Israel's capacity to colonize, subjugate, and occupy Palestinians in the OPTs is dependent on the historical dispossession and accumulation of Palestinian land and the control of essential resources such as food and water. This chapter first assesses the essential "accumulations" that are presently occurring in Palestine by the Israeli polity, providing the foundations for the colonizing state to successfully atomize Palestinians, breaking apart their historically produced solidarity, in order to "remold" their consciousness into an Israeli or Zionist ideal - a docile society that will "willingly" participate in capitalism and thus, their own exploitation and oppression. These essential "accumulations" required for the theorized remolding of Palestinian consciousness include first, the containment or the policies of closure that have rendered the OPTs a series of disconnected enclaves (Peteet 2017). Second, the expropriation of indigenous foodways that existed as a means for Palestinians to sustain themselves independent of the colonizing state and its imperialist allies (i.e. the capitalist world) (Zurayk and Gough 2013; Saranillio 2015). Finally, occurring throughout and preceding each accumulation, the shock of bodily and mental violence against Palestinians straining their society's ability to heal and thrive while also terrorizing and ultimately, threatening them with extermination. The military capacity of Israel, and its allies, combined with the powerfully discursive demonization of the Palestinian that has moved from labeling them as savages, primitives, and beasts to a modern discourse of terrorists and "jihadists," seemingly putting them at risk of massacre. Instead, the Israeli regime has adopted a policy of maiming that breaks the body and strains family units by increasing the number of disabled Palestinians (Puar 2017). 
Together, these three processes work to map the availability of atomization that provides the conditions necessary to mold Palestinian consciousness. Following the examination of the “accumulations" of Israel, Walid Daka's (2011) profound observation and analysis of the policy changes in Israeli prisons are introduced. These various, seemingly harmless, policies work to individualize the politics and deter the collective organizing that was once critical to the Palestinian prisoner experience, indicating and providing evidence of atomization in the prisons. Daka suggests that the enclaves in the OPTs, described by Peteet (2017), are the basis for Israel's "final-solution." A hypothesis that suggests the final stages of the colonization of Palestine are in motion. Daka's essay inspired me to think about the various brutal and life-threatening conditions Palestinians are subjected to in Gaza and the West Bank as a strategy of divide and conquer.

Daka argues these policies that divide and destroy collective resistance in the prisons will be, or are being, replicated in the OPTs. Thus, following his observations in the prisons and his hypothesis of Israel's "final-solution," I theorize atomization as a strategy of colonial and capitalist domination through the contributions of theorists and writers analyzing society and social change. They, much like myself, were trying to make sense of the European history of domination that culminated in their present conditions and have continued to form our current economic, cultural, and political conditions that mark our "modern" capitalist world.

Connecting capitalism to colonialism, atomization links the two as their modular method to end indigenous uprisings in the colonies and to smother worker resistance in the capitalist centers of Europe. I argue that understanding and examining the past is the only way to unpack and critically examine modern systems and structures such as capitalism and setter colonialism. Atomization works to link these histories and structures. The contemporary occupation of the 
Palestinians in the OPTs is directly linked to the exploitation of workers, women, queer people, black people, the undocumented workers in the U.S. and all other oppressed and marginalized groups in capitalist societies. This is because Zionism and the capacity for the early Yishuv in Palestine to overwhelm and expel Palestinians from their homes in 1948 was only made possible by industrial capitalism. The "development" of capitalism required the violent destruction and pulling apart of the solidarity of the working class and peasantry that had developed after the Black Death and Peasant Wars in the 14th century which led to the end of oppressive feudal relations. This history is documented by feminist-Marxist scholar Silvia Federici (2014) who writes on the process of "primitive accumulation" that was necessary for the creation of capitalism often speaking to atomization when describing the strategy of the ruling classes (aristocrats and capitalists) to upend egalitarian relations found in worker and peasant cultures. Federici's work paired with Daka's theory of consciousness remolding and the various researchers of the Palestinian condition in the OPTs links colonialism, settler colonialism, and capitalism to atomization. Across each system, structure, and process atomization is necessary to end the resistance of those who demand a more egalitarian existence, and to continue the everexpanding conquest of capitalism - the modern colonial venture. Thus, the primitive accumulation of "enclosures" in 16th century England, when collective lands and the commons were privatized by lords and rich farmers that subsequently destroyed peasant society, inconsequently parallels the Israeli policy of closure in modern occupied Palestine. 


\section{Containment and Isolation}

The recent formation of the enclaves that divide Palestinians from one another has been enabled by processes of historical segregation and the policies of closure that began after the Oslo Accords (1993) and accelerated after the Second Intifada (2000). First, in the early 20th century, land policy of the Jewish National Fund made it illegal for Jews to sell land to nonJews. This policy of denying the transfer of land rights to Christian or Muslim Palestinians led to the emergence of ethnically and religiously dichotomist, semi-homogeneous spaces that reflected the Zionist, and European, consciousness of "us" and "them." Though segregation was the norm, economic and cultural exchange occurred between Palestinians and the recently arrived European Jews, albeit being unbalanced as Palestinians remained in a marginalized and dominated position in the Mandate period and the early days of the Israeli state. With the Oslo Accords (1993, 1995) Israel radially ramped up policies of physical and legal containment of Palestinians. This is evident by the words of Israeli Prime Minister Yitzhak Rabin who in 1994 said, "[W]e have decided on separation as a philosophy" (Makovsky 2004: 52). The Oslo period is marked by the construction of the separation wall, the implementation of a more complex permit system, the proliferation of the checkpoints, draconian restriction on movement, and the carving up of the West Bank into different administrative zones that culminated in the carving out of enclaves.

In 2002, Israeli Prime Minister, Ehud Barak made the decision to begin the construction of what is now an eight-meter-high and estimated 434 miles long concrete wall that weaves between towns and farms, piercing through the Palestinian landscape (Peteet 2017: 41). Historically, walls have been employed throughout human history in order to separate groups of people from one another. Importantly, walls separate along discursive lines of "us" and "them," 
as Peteet remarks, "[T]he wall has a historical place in keeping out the barbarian and protecting "civilization"" (ibid.: 42). Thus, the Israeli separation wall, like most walls in history and the contemporary policy headline of Trump, serve to demarcate people into categories of inclusion and exclusion, civilized and uncivilized. Marking the landscape as a physical reminder of domination and separation, the wall winds in and out of the internationally recognized borders of the West Bank, incorporating illegal Israeli colonies and separating Palestinians from Israelis, from their land, and from one another. In confining and segregating Palestinians in between these walls and checkpoints, Israel has spatially molded Palestinians into a series of discontinuous enclaves.

According to Peteet's research on the spatial confinement of Palestinians, the enclaves are comparable to prisons in that they contain an expelled population whose mobility is controlled and surveilled (2017: 44). The enclaves can be compared to the Bantustans of Apartheid South Africa and the Jewish ghettos of Europe, but crucially different is extent of the segregation and isolation in the OPTs. Even amongst the Jewish ghettoes and the Bantustans, there was a higher degree of economic and social diffusion. Furthermore, there are over 160 enclaves that make up the West Bank, rendering the space of Palestine into an archipelago. Gaza, on the other hand, has become one large enclave, often described as an open-air prison (ibid.: 44). In the West Bank, this archipelago of sorts is formed through the combination of Israel's physically impeding separation wall and physically threatening system of checkpoints and permits that demarcate the zones that Palestinians are confined to.

In 1991, checkpoints began to spring up around Jerusalem and by 1993 they were strewn throughout the 1948 Green Line placed strategically in between Palestinian towns in the West Bank (Peteet 2017: 70). In addition to the checkpoints, the existing permit system for 
Palestinians was expanded and limitations to movement increased, especially after the first Intifada in 2000 (ibid.: 70). Peteet calls Israel's system of permits for Palestinians, a "paper wall of bureaucracy" because it limits the mobility of Palestinians and subjects them to arbitrary immobilization when they are denied access through checkpoints without any given reason or citation (ibid.: 85). Checkpoints in the West Bank take many forms that include small stations on country roads, large complexes that resemble a fortified airport terminal, temporary sites that spring up overnight, and the arbitrary stopping and searching of buses and taxis. Much like the walls and permits that entrap Palestinians, the checkpoints organize and display separation, monitoring and managing the speed and breadth of Palestinian mobility (ibid.: 100). Although the checkpoints hinder Palestinian mobility, the checkpoints themselves can move at hyper speeds, signifying the extent of power and control that the colonizing state of Israel has over the occupied population. Together, the walls, permits, and checkpoints used by the Israeli state work together to contain and immiserate the Palestinian population. By containing and controlling the colonized population and then removing their capacity to thrive and sustain themselves, Palestinians exist at the hands of their captor.

\section{"Calculated Starvation"}

Palestinian children in Gaza are on what the Israeli military leadership has called a starvation diet. You have almost 80 percent of Palestinian children living on less than $\$ 1$ a day. They're at levels of what we would call poverty and extreme poverty, with extensive food insecurity. That's just another way of saying that most Palestinian children in Gaza go to bed hungry every day, so their caloric intake has been significantly reduce since the siege began within the last seven years. In addition to the reduced number of calories they take in, the kind of nutrients they're getting is also decreased, so what we see is this medical phenomenon called stunting, which results in lower birth weights for Palestinian children... Dr. Jess Ghannam (2014) quoted in Said and Zahriyeh. 
Atomization is ultimately about removing a people's access to power that is fueled by their unity and solidarity. When indigenous foodways are threatened or destroyed by colonial actors, the indigenous population loses their primary ability to provide for themselves resulting in their coerced dependency and participation in the colonizer's mode of production. The primitive accumulation of land and foodways is a necessary precursor to atomization and domination. Writing on settler colonialism in the context of Hawaii, Saranillio concludes that "[T]his process of primitive accumulation and its ongoing process of 'accumulation by dispossession' divorces a people from the means of production - from their ability to provide for the basic necessities of life - and they are then forced to live through wage labor" (2015: 291). Being enclosed behind walls and checkpoints, often severing Palestinians from their own ancestral olive groves and lemon orchards, they have been rendered unable to fully provide for themselves. The ability to create this condition lies in Israel's control of the air, land and sea borders of Palestine: Israel has maintained sole control of what comes in and what goes out. Basic needs of Palestinians have been calculated by the Israeli state and made available but allocating only the bare minimum creates a constant risk of hunger or on the edge of starvation, and debility (Zurayk and Gough 2013). Israel's denial of land rights to Palestinians makes them available for oppression and immiseration as they are forced to rely on the "benevolence" of their colonizers and the international humanitarian regime funded through their colonizer's allies. This section examines Israel's control of Palestinian food supply through extensive dedevelopment, de-peasantization, and subsequent dependency.

First, Gaza's historical landscape must be established for context. When the Zionist project to colonize Palestine materialized in 1948 with the creation of the Israeli state, more than 700,000 Palestinians were expelled through coercion and violence and denied return; around 
200,000 of these took refuge south of the newly established Israeli border in Gaza. Since then Gaza has expanded to a population of $1,486,816$ in 2009 , with 73.3 percent registered as refugees, making this region one of the most densely populated in the world (Rami Zurayk, et al. 2012: 1). Gaza remained under Egyptian administrative rule until 1967 when Israel began its occupation and over the years created 26 colonies hosting around 6,500 settlers (ibid.: 1). After the Oslo Accords in 1993, the OPTs were granted the right to hold elections for local governance and in 2006, Hamas, the Islamic Resistance Movement, won control of the Palestinian Legislative Council, triggering economic sanctions from Israel (ibid.: 2). In 2007, Israel imposed an all-encompassing blockade that to this day restricts exports and imports that includes, "food and agricultural inputs, people's border crossing, and access to land and fishing waters... it also imposes frequent cuts in the provision of fuel and electricity... and the enforcement of vast access-restricted areas (ibid.: 2). This blockade effectively cut Gaza off from the outside world and other Palestinians in the West Bank, ultimately giving Israel full control of Gazan's livelihoods. The cage was built, and Israel gained full control of the resources that came in and out.

Beyond the economic blockade, Israel has strategically complicated the basic requirements that Gazans need to sustain themselves. Through land-grabs, restricting access to agrarian lands, and altering production, Israel engages in depeasantization: the destruction of sustainable agricultural communities by states that typically coerce the population into wage labor and economic dependency on the state's capitalist markets. Currently 29 percent of Gaza is designated as an access-restricted zone which means Palestinians have no access to the land and are met with violence and possibly death if trespassed; although a total of 46 percent of arable land is unusable due to Israeli destruction and the use of internationally banned phosphorus 
weapons that toxify the soil (Zurayk and Gough 2013: 21). The dangers of restricted zones are exemplified by 12-year-old Iman al-Hams who wandered into a restricted-access zone and was executed by an Israeli Defense Force (IDF) commander in 2004 (Li 2006:46). Similar to farmers, fishermen are limited to a mere three nautical miles off the shore of the Gaza Strip, even though the Oslo Accords provided twenty nautical miles (Zurayk and Gough 2013: 29). These restrictions have almost entirely wiped out the fishing industry of Gaza that was once famed in the region. Before, supporting around 60,000 fisherman, the remaining 4,000 registered fishermen are mostly unemployed (ibid.: 29). While most of the farmable land and fishable waters are barred from Gazans, the remaining usable farmland is used for commodity crops that Gazans are coerced into producing for export, replacing sustainable agriculture.

Encouraged by Israeli policy and the international community, many Gazan farmers have resulted to "cultivating high-niche exports like strawberries, cherry tomatoes, and cut flowers (Zurayk and Gough 2013:28). A feature of the modern food regime is the heavy use of chemical inputs and the utilization of credit; this is the same for Gazan farmers who grow these cash-crops in greenhouses. In 1994 the Dutch government funded an aid project for the production of cutflowers in Gaza with the goal of economic development for Palestinians by providing them the means to produce goods to sell on the capitalist market. In the end, Israeli agricultural corporations mainly profited from providing chemical inputs and acting as mediators for the flowers' export (ibid.: 35). This is evidence that even the yield of cash-crops is subject to exploitation by Israel: Gazans labor for the profit of Israel and in return Gazans receive poor wages, if any at all, and, in the end, have nothing to eat or own from their agricultural yield. Another tactic used by Israel to undermine Palestinians self-sustainability is the policies and practices of underdevelopment. Unlike an underdeveloped economy in which political and 
economic components for development exist, a de-developed economy is "deprived of its capacity for production, rational structural transformation, and meaningful reform, making it incapable even of distorted development" (Roy 1999: 65). Throughout the history of the occupation of Palestine, the economic relationship between Israel and the OPTs have been marked by the same three features: Israeli control of Palestinian economic resources such as water, land, construction materials, and zoning; trade conducted solely through Israel while the economic connection between Gaza and the West Bank severed; and restricted institutionalization to hinder structural change (ibid.: 66). The most damaging aspect, discussed further in the next section, has been the intermittent destruction of Gaza's infrastructure that includes agricultural lands, sewer and wastewater treatment plants, and places of social services such as schools and hospitals (Zurayk and Gough 2013: 21, 23). Harking back to the previous discussion of closure and containment, a defining feature of Israel's planned de-development, is the creation of enclaves that isolates markets and forces an economic relationship between Palestinians and the Israeli markets (Roy 1999, 68). Gazans' restricted access to agricultural land and the push for the remaining Gazan farmers to produce commodities for export in a landscape of underdevelopment, positions the region to rely on Israeli imports and international food aid, which ultimately sets up Palestinians for exploitation and domination.

Through processes of de-peasantization and de-development, Palestinians are made captive consumers to the Israeli markets. With little access to their own agricultural lands, a lack of water because of Israeli syphoning, and Israeli-controlled borders that limit necessary equipment for agriculture, Gazans are left dependent on Israel for their basic needs. This relationship is then brutally enforced through colonial relations in which Israel controls most of the political and economic activity of Palestinians and resistance is met with violence and 
increased economic blockades. Gaza is a special case in which all sides of the region are surrounded by walls and the sea is blockaded - resulting in their total containment in an openair prison. Thus, Gazans are not only captive consumers, they are imprisoned consumers. Comparable to the contradiction in the neoliberal food regime where peasants are made poor consumers who must rely on cheap imports and international food aid, Palestinians in Gaza have been made impoverished and imprisoned consumers who cannot afford the food provided by the Israeli market.

As Gazans must then rely on international aid to afford food on the Israeli market or obtain food through surplus dumps, the dilemmas of modern food security discourse and action in the context of the world's modern food regime become clear. Otero et. al.'s (2013: 263) argument that food security in neoliberal regimes is marked by uneven and combined dependency is apt for the context of the colonial relations between Israel and the OPT. As Israelis enjoy access to luxury foods and the ability to determine how and where they obtain food, Gazans are forced to rely on cash assistance to purchase expensive food provided by the Israeli market; thus, most sustain themselves on food aid packets that contain "fortified wheat flour, cooking oil, dried milk, lentils, rice, and sugar... not sources of all requisite micronutrients" (Calis 2017: 68). In Bernstein's discussion of food regime theory, during the second regime 2 of U.S. hegemony, food aid was developed as a means to unload surplus foodstuffs from developed nations (Bernstein, Henry 2015: 1). As Israel does not allow Palestinian communities to access their basic entitlements of land and clean water, the ability for these populations to be self-sustaining is made impossible. Instead, the colonized population of the OPTs is sustained

2 The first food regime, according to Friedmann and McMichael (1989), took place from 1870-1914, which was marked by farming in settler colonies in the culmination of colonialism and British hegemony in the world market. 
with bare minimum access to food that does not provide proper nutrition, fending off famine while maintaining Israeli domination.

In turning our attention to the West Bank, the agricultural village of Jayyus is a prime example of a once vibrant, self-sustaining peasant culture that has been altered through Israeli use of physical and structural violence. This case-study exemplifies the imbricated nature of Israel's control of Palestinians' means to sustain and thrive. Jayyus is located in a region known as the "food basket of Palestine" and "still has the highest percentage of cultivated land of all the West Bank districts" (Calis 2017: 68). In April 2002, the Israeli government announced plans to construct the separation barrier that, unbeknownst to Jayyus' residents, would cut off $75 \%$ of the villages' agricultural lands (ibid.: 68). The town only became aware of this through discovering IDF announcements nailed to trees in the area. Landowners had one week to file appeals, all of which were rejected on the grounds of military necessity. These lands were marked for demolition and "[I]n November 2002, military-escorted bulldozers entered Jayyus without announcement and began the process of uprooting more than 4,000 olive trees," and some farms were "immediately leveled and destroyed to create the footprint of the Wall. These farmers helped to form a nationwide Stop the Wall Campaign" (ibid.: 68). The wall's construction cut off "120 greenhouses, 15,000 olive trees, 50,000 citrus trees, cereal crops, and livestock" in addition to the village's water resources; six out of seven wells (ibid.: 69). The enclosure of Jayyus with the separation wall laid the path of Israel's land confiscation. Jayyus', and the West Bank's, ability to produce its own food was severely damaged, increasing their reliance on Israeli markets to provide food.

The combination of Israel's de-peasantization, de-development, and enclosure has resulted in a shift in Palestinian culture and economics: the abandoning of agriculture. With that, 
the ability for Palestinians to sustain themselves and develop a foundation for a sovereign nation and liberation are made impossible. Israel's mission of de-development in and of itself is a political mission to force Palestinians' reliance on their markets, further entrenching the colonial relations between Israel and the OPT. If any progress is to be made in the way of liberation, it will be marked by the ability of Palestinians to sustain themselves and intervention from the international community to end Israel's starvation of Palestinians. Much like the process of primitive accumulation of the commons, a source of peasant sustenance and power, in the 16th century, Israel must destroy the means for Palestinians to support themselves to strengthen their colonial control of the population and to smash a possible source of indigenous empowerment.

Maiming and Debilitation

The violence that is the calculated malnourishment and forced dependency on Israeli markets pairs with the colonial regime's intentional debilitation of Palestinians to produce a state of endless shock and trauma with few means for Palestinians to heal. At the end of the first chapter in Space and Mobility in Palestine, regarding Israel's closure of the OPTs Peteet asks, "[W]hen and under what conditions does disposability occur?... What are the early signs of abandonment?" (2017: 64). After observing the many ways in which Israel has enclosed and constricted Palestinian life behind walls, checkpoints, and paper walls of bureaucracy, Peteet ponders if the captive population of Palestinians has been left to decay, alone. The question of abandonment exists as a paradox in the case of Israel because of Israel's withdrawal and closure of Occupied Palestine with the simultaneous hypervigilance and apparatuses of control that Israel uses to suspend and monitor Palestinian lives (ibid.: 65). If it is the case that Israel has the intention of extracting resources such as labor and capital from an otherwise refuse population, 
then closure is not a form of abandonment, but instead a form of containment. The work of Jasbir Puar (2017) provides a powerful argument of Israel's “primitive accumulation" of the Palestinian body, where the targeting and maiming of the colonized body serves to strain social units, weakening their capacity to resist, and to provide a means for capital exchange.

Jasbir Puar argues that Israel 'manifests an implicit claim to the 'right to maim' and debilitate Palestinian bodies and environments as a form of biopolitical control and as central to a scientifically authorized humanitarian economy" (2017: 128). Here lies the means in which Israel extracts capital from a population that otherwise seems abandoned. What Puar calls a "speculative rehabilitative economy" exists through a combination of international actors and Israel's policy of maiming (ibid.: 128). This metaphorical battery's energy is intermittently absorbed and regenerated through a process of destruction and rehabilitation. This Israeli tactic has moved Palestinians as a population available for injury into a population that is targeted to be injured. This framework relies on the internationally acceptable biopolitics of "let live," understood as less violent and more acceptable than killing (ibid.: 129). Thus, "shoot to cripple appears on the surface to be a humanitarian approach to warfare" that allows for its continuation as it alludes to the intent of the colonial state (ibid.: 129). A prime example of how the internationally accepted policy of "let live" obscures the reality of suffering for Palestinians is the "roof knock," which is a preliminary minute explosion that alerts civilians to seek shelter. This seemingly merciful act is a gimmick when "the capacity of mobility circumscribes the reality of the roof knock," such as in the 2014 bombing of Mubaret Philistine Care Home for Orphans and Handicapped in Gaza where three disabled residents died (ibid.: 129). The immobility of disabled Palestinians and the immobility of Gazans as a whole, stranded in the 
open-air prison, makes the 60 second warning strike more so a sick bell toll for their impending demise.

The first signs of a maiming policy began when medical personnel in the OPTs reported a notable increase of "shoot to cripple" events and discourse during and after the first intifada (ibid.: 129). Anti-riot weapons like rubber coated bullets that were once used to disperse crowds by shooting around bodies, exploding into shards and superficially injuring those around it, are now aimed at protesters femurs, arms, and vital organs that on impact rupture flesh, break bones, and damage organs (ibid.: 129). Recordings of maiming began around the time of the first intifada such as Al-Haq's report Punishing a Nation: Human Rights Violations during the Palestinian Uprising: December 1987-December 1988 brimming with evidence of the intent and effect of maiming Palestinians by Israeli forces. During this time, defense minister Yitzhak Rabin commented about the new use of plastic bullets "to increase the number of (wounded) among those who take part in violent activities but not to kill them" (1988: 16). The West Bank Database Project reported the increase of Israeli forces firing weapons as a part of deterrence instead of defense, "shooting first at an 80-degree angle in the air, and then, with intent to injure, at the legs" (ibid.: 16). During the second Intifada from 2000 to 2005, the Israeli army began using internationally banned dumdum bullets that burst in the body, are difficult to remove, and those who are hit will usually "suffer for life" (Puar 2017: 131). Sergeant Roz, an Israeli sharpshooter with the Nashon Battalion, was quoted saying, "I shot two people... in their knees. It's supposed to break their bones and neutralize them but not kill them" (Reinhart 2002: 113). These tactics align with the humanitarian mercy of "let live" as Israel is well aware of the negative attention they would receive if they were deliberating killing Palestinians at the rate in which they were injuring them (ibid.: 114). 
Beyond the intentional maiming of Palestinians to subdue them permanently, Israel has actively hindered emergency medical services. According to Al-Haq, the obstruction of medical care in war zones and occupations is not new but since the first Intifada, the "[V]iolation of medical human rights have occurred with frightening regularity during the past years in all parts of the Occupied Territories" (1988: 70). These medical obstructions include, "blocking ambulances and cars transporting the sick and injured, raiding hospitals and clinics, denying medical teams' access to areas under curfew, withholding medical treatment from prisoners, and deprioritizing the 'right of the wounded to medical treatment'" (Puar 2017: 133). Furthermore, during the second Intifada, it was reported that Israeli forces attacked Palestinian healthcare providers who were in the midst of helping the injured and dying (Jamjoum 2002: 56). The Palestinian Red Cross Society reported that during the second Intifada 78 of their 100 ambulances were damaged, totaling 174 attacks made on its ambulances, and 166 attacks were made on its emergency personnel while machine gun fire targeted their headquarters (ibid.: 56). These instances go beyond Israeli forces intentionally maiming bodies and implies they are also debilitating infrastructures. Hindering the medical response of intentionally injured Palestinians brings up the question of Israel's biopolitics: is it truly a state that follows the humanitarian "let live?" What kind of life is left when the body cannot heal?

Achille Mbembe (2003) writes that the assaults on infrastructure in the context of the OPT and Gaza where residents are trapped amounts to a "war on life support: when the capacity of the 'state' to preserve and nourish life is reduced to nothing, there exists a war on life itself." This is evident by Israel's long assault on Gaza's agricultural, water, medical, and electrical infrastructure that simultaneously leaves Gazans unable to support their society with basic needs and the severe inaccessibility of clean water, electricity, and sewage creates dangerous health 
outcomes. In 2014, Gaza's water infrastructure collapsed while waste treatment plants shut down, flooding the streets with raw sewage. To make matters worse, several water authority technicians were killed by Israeli forces, so the treatment plants remained in disrepair (Hass and Efrati 2014). The killing of skilled personnel became a tactic of the infrastructural war on Gaza during Operation Protective Edge: "[T]he targeting of the professional class, a key pillar of Palestinian society generally considered unsympathetic to the political goals of Hamas, was a new front of economic and social warfare on Gaza" (Cohen: 2014). Destroying the physical infrastructure of Gaza was clearly not enough, instead, the experts capable of repairing the damaged facilities were targeted in an effort to maintain the state of emergency and reduce the little economic power that these professionals had. Israel's ability to target infrastructure in this manner was enabled by discursively eliciting notions of security by documenting the zones as “terrorist infrastructures" (Salamanca: 2011). Salamanca argues that this infrastructural war is an integral component in Israel's biopolitical and colonial control of Gaza that ultimately gives rise to its remote ability to control humanitarian collapse, the trigger that summons international response and aid (ibid.: 25).

After Israel's 2005 withdrawal of its colonies from Gaza, it appeared to the international community that Israel had "disengaged" from Gaza. Yet Israel retained its absolute infrastructural control of Gaza, existing as a "regime of spatial control" that works to manufacture humanitarian collapse (Salamanca 2011: 26). This remote, spatial control of occupied Gaza is what Sari Hanafi calls spacio-cide in which "the terrain is dependent on the withdrawn colonizer's infrastructural support, which modulates calories, megawatts, water, telecommunication networks, and spectrum and bandwidth allocation to provide the bare minimum for survival" (Puar 2017: 134). The single fiberoptic cable that provides bandwidth to 
Gaza runs from Israel and in this additional control of Gazans' virtual world, Israel has created a physical and high-tech enclosure that Puar argues is "the epitome of an asphixatory regime of power" (ibid.: 135). The power to asphyxiate Gazan society is the power to create humanitarian crisis at any given moment. Jasbir Puar notes while the West Bank is controlled by checkpoints and permits, Gaza is controlled through "choke points" (ibid.: 135).

A major aspect of the infrastructural control of Palestinian society is the subsequent slow death that is materialized in the physical deceleration of Palestinian life. In the West Bank, Israeli settlers move with uninterrupted speed on freeways that are barred to Palestinians. Instead, Palestinians must traverse dilapidated roads and are forced to wait at checkpoints that dot the landscape and stretch the physical distance between any two Palestinian points in space. As discussed earlier, checkpoints hinder all aspects of West Bank Palestinians economic and social lives that Puar argues creates "an entire population with mobility disabilities" (2017: 136). Mobilities such as these are mapped on a framework of modernity and orientalism that posits the "civilized" as possessing hyper speed and progression while the "primitive" moves slowly, trapped in space and time. In reality, from the evidence provided of Israel's control regime, the "civilized" (Israelis) immobilize and suspend colonized populations, rendering them slow and incapable of thriving. The colonizers create a structure of slow death for the colonized population for the benefit of the colonizing state and society that extracts resources and labor from the colonized.

Israel's settler colonialism exists not merely as a process of slow death for its colonized population, but instead as a process of maiming. According to Puar, maiming is differentiated from slow death by its character of "slow but simultaneously intensive death making" that stretches the temporalities of life and "the finality of death into perverted versions of life" that 
feel like neither life nor death (2017: 139). In this model, life itself and importantly, resistance to the process, becomes a target of "neglect, damage, and speculative rehabilitation" (ibid.: 139). In slow death, the policy is "let die" through the slowing of life and health or "make die" through the state's ability to kill, but maiming exists as "will not make die" (ibid.: 139). In this distinction lies the humanitarian community's grave mistake in viewing maiming as "let live," as if injuring bodies in a debilitated state is conceivable as merciful. When the international community affirms that the IDF's (Israeli Defense Force) policy of shooting to maim is the preferred preservation of life instead of the taking of life, the mechanism of Israel's colonialism continues to churn. Because of this, Israel continues to dominate and exploit Palestinians through the politics and morals of humanitarianism. Puar argues that "this foundational biopolitical frame is a liberal fantasy that produces 'let live' as an alibi for colonial rule and thus indeed facilitates the covert destruction of "will not let/make die..." and that this fantasy must be challenged through the vantage point of those that exist in suspended suffering, domination, and exploitation: the colonized Palestinian (ibid.: 140). After recognizing the mechanism of maiming, it must be asked; how does Israel benefit from a colonial policy of "will not let die"? And how does Israel capitalize from maiming?

Israel's maiming of its captive population, Puar argues, is the end goal of Israel's settler colonialism because "in the dual production of permanent disability via the infliction of harm and the attrition of the life support systems that might allow populations to heal from this harm" combined with Israel's remote control of humanitarian crises triggers response from the international aid regime, states, and NGO actors (2017: 143). In this humanitarian response lies economic and ideological profit that benefits Israel, the hegemonic order led by the United 
States, and some Arab states. The geopolitical order that exists in the Middle East as a modern network of imperialist forces sustains the domination and exploitation of Palestinians.

The humanitarian response to the recurring Israeli destruction of Gaza feeds back into Israel both economically and ideologically by international actors who, like Israel, calculate "Palestinian life, death, and debilitation according to different economic, geopolitical, and domestic metrics (Puar 2017: 145). In the case of Arab Gulf states, their benefit in the rehabilitation of Gaza through their massive investment projects is the indirect political and economic gain protecting their favored status among the hegemonic and capitalist order that is led by the United States (ibid.: 145). On a similar note, Egypt has long benefited in this order by being rewarded military aid and support from the U.S. in exchange for maintaining security on Israel's western border and more recently cutting off the stream of basic goods into Gaza, all the while condemning Israeli attacks on Gaza (ibid.: 145). In the NGO complex, Max Blumenthal reported that consulting teams overseeing Gaza's private rebuilding imagine "a future of sweatshops producing zippers and buttons for Israeli fashion houses" (ibid.: 145). Then there is the conundrum of the UNRWA that is mainly funded by Western states and specifically the U.S. who is simultaneously providing ammunition and international aid to Israel that funds the destruction of UNRWA schools and hospitals (ibid.: 145).

The recurring crises in Gaza ultimately feed into models of disaster capitalism where Gaza serves as Israel's laboratory to experiment, to destroy, to let rebuild, and profit. During the first months of Operation Protective Edge in July of 2018, Joseph Pugliese reported that the drone company, Elbit, saw a six percent increase in profits after their drones were field-tested on Gaza (2015: 3). After each destruction, “donor conferences raise billions of dollars for rebuilding infrastructure in Gaza," that ultimately ends up feeding back into Israel as Gaza will inevitably 
be destroyed again (2017: 145). The expected donor-fatigue from this never-ending cycle is overcome because it is much easier to donate money than to truly address the source of destruction (Dyke 2014). This industry of destruction and rebuilding makes the captive and debilitated Palestinian population, that is no longer used as a source of labor, profitable to Israel. As Puar puts it, "Gazans must be debilitated in order to make (their) life (lives) productive" (2017: 146). Israel's model of a productive body under late capitalism, is a body that is debilitated: not dead, not living, but suspended in a space in-between life and death that can be used to trigger instantaneous capital accumulation.

Israel's policy of "will not let die" in order to generate capital and influence through the mechanisms of humanitarianism and capitalism, positions the Israeli state as not an apartheid state, which it is often described as, but a "post-genocidal state". Whereas Nazi Germany was a genocidal state that utilized the biopolitics of "make die" as a means to eradicate Jews and undesirable populations considered refuse, Israel is forcing Palestinians to live in-between life and death, in a state of injury and trauma in order to extract capital as a modern form of primitive accumulation.

Although Israel is the primary actor and agent of this morbid machine in Gaza, it is the political-economic system of capitalism that enables it and arguably, encourages it. As capitalism's constant expansion requires ever new markets in a finite world, what is the perfect market but one that is destroyed and rebuilt with instant capital from external agents? There is evidence that capitalism encourages Israel's actions because those that govern the major centers of capitalism, continuously reaffirm Israel's actions while deflecting Palestinian suffering. These capitalists who lead the economic empire are the same ones benefitting from Israel's postgenocide machine and use the same discursive techniques to warrant the exploitation and 
domination of marginalized people across the world whether they be "terrorists," "thugs," or "illegals." In our modern times, the discourse of "security" elicits society and the military power of the state to evade ethics, morals, and human decency, ultimately enshrining white supremacy, colonialism, and capitalism. In order to continue these operations, it becomes necessary to quell the inevitable resistance of the oppressed and exploited. For Daka, resistance will be most effectively overcome through the remolding of Palestinian consciousness, altering their awareness of their own condition under colonialization and capitalism.

\section{Colonizing the Soul}

Through containing the Palestinian population in the enclaves of the West Bank and the open-air prison of Gaza, Palestinians are politically and spatially divided and isolated. Through expropriating their indigenous foodways and controlling their agriculture, Palestinians are forced to cooperate with capitalism and are made dependent on Israel and international aid. Through constant aggression against captive Palestinians and their infrastructure, they are made debilitated and maimed. Israel has set the conditions to level Palestinian resistance. This section theorizes atomization through the observations and hypothesis of Walid Daka, the contributions of social theorists, and by drawing historical comparison to the violent creation of capitalism in 16th Europe as documented by Silvia Federici.

Federici's (2014) work ties the formation of capitalism in Europe to the processes of colonialism, settler colonialism, and thus, Zionism's settler colonial project in Palestine. Maintaining these systems of oppression requires a significant amount of force to continue the subjugation of the exploited. Federici illuminates the struggle between egalitarian social relations had by peasants and workers, following the demise of feudalism in Europe, and the hierarchal 
and exploitive social relations of the aristocrats and bourgeoisie (capitalists). The struggle between classes was a battle over the social arrangement of power-either to be diffused and balanced across the social order or to be accumulated and concentrated solely in the ruling classes. As seen through the critiques of Marx and Karl Kautsky, the nation-state would be a crucial manager of the power consolidated by the bourgeoisie of Europe, which ultimately served as an organized military of the ruling classes that enforced their control and domination through the threat of elimination and persecution. Crucial to this revolution against egalitarian society (peasantry and working class) was the primitive accumulation of their sources of power, specifically, collective land known as the commons (2014: 71-72). But to successfully upend egalitarian relations once and for all required a more difficult task - the remaking or remolding of working-class consciousness (ibid.: 103). To be aware of one's individual oppression is a useful weapon in of itself, but for an entire social sector (peasants, urban workers, Palestinians) to be aware of their oppression and to remember the violence that was the ruling classes' (or colonizer's) means to accumulate their land and power, is an unstoppable force. Thus, awareness and memory became the target of the ruling classes' war against egalitarian society in 16th century Europe. Similarly, Walid Daka (2011) analyzes the Israeli war against Palestinian consciousness and memory to quell their resistance to colonization through Foucault's (1975) notion of discipline.

Discipline and the Individual

Referencing the work of Michel Foucault, Daka contends that "modern oppression is hidden," that the exploiter, the oppressor, is faceless, omnipresent, and through its "monopolist arms" reaches into every part of your life, possibly even making you a participant in your own 
domination (2011: 234). This "modern" oppression is comprised of small, seemingly isolated acts, that do not appear to be a tool of torture or violence at least not until these fine details are fitted together (ibid.: 234) In Discipline and Punish, Foucault (1984 [1975]: 189-202) describes discipline as a series of meticulous, seemingly benign (in appearance), processes that aim to produce a docile body with utility value. These processes include constant, or what is perceived as constant, hierarchical observation, normalizing judgement and punishment, and examining individuals to make each body legible and analyzable. Together they create a structure that penalizes agency and normalizes coercion and domination. Docile subjects with utility value are the result. Foucault stresses that the structure itself limits the ability of its agents to recognize their own subjugation and thus unlikely to resist. The processes and structures remain hidden, obfuscated by their normalization, while the individual body is made visible, measurable, and controllable. Breaking from Foucault's overemphasized structure, subjects in a "social hegemony" of discipline, where power of the structure is reproduced by its agents, may actively want to participate in their own disciplining because it is supported and encouraged by their families and peers. In order for this hegemony to be enmeshed into society, the former social institutions and cultures must be unmade. In a snowballing effect, initial violence and coercion produces and reproduces networks of power that enable and encourage agents to use violence and torture to atomize, or break apart, the former social order. This process can occur both ways. Actors who resist may build opposing networks of power that enable and encourage violence against the current oppressive order and build unity and solidarity to unmake the social hegemony of domination and discipline. The Israeli state, which includes its prisons, is a network of power supported by an advanced military and a series of external power networks, 
the United States in particular, that enables the torturing, killing, and maiming of Palestinians. This enabled violence is the first step to atomization: the shock phase.

\section{Atomization of Palestinian Prisoners}

Daka argues that the Israeli prisons are sites of experimentation where the tactics to disable and destroy Palestinian resistance in the OPTs are realized. It was in 2003 when Yaakov Ganot was appointed by then Prime Minister Ariel Sharon to head the Israeli Prison System (IPS) and when the process to break and remold the Palestinian leadership of the National Prisoner Movement3 began. This period of shock tactics, as described by Daka, began with the first wave of mass invasions and arrests of Palestinians throughout the OPTs during the Second Intifada. Following this, Yaakov Ganot implemented severe suppression of prisoners and implemented new policies provoking an open-ended hunger strike. These policies included frequent and erratic strip searches, the use of dogs to search prisoners and move them between prisoners (in many Muslim cultures dogs represent pollution so this would be comparable to rats or rodents), and outfitting the visiting rooms with plate glass so that prisoners could not touch their families (2011: 241). To break the strike, the IPS began leaving lights on day and night, salt was confiscated (salt prevents permanent damage during hunger strikes), prisoners were transferred between rooms and wards constantly to break up their social groups, fliers were distributed to circulate rumors that Hamas initiated the strike or a member of the political party Fatah broke the strike, daily barbeque parties were held for non-Palestinian prisoners, cattle prods were used to move prisoners, and lawyers were prevented from contacting prisoners thus isolating them from any information about the solidarity movement outside the prison walls

3 The National Prisoner Movement refers to the organizing efforts of Palestinian leaders within Israeli prisons. 
(ibid.: 243). Together, these rules effectively turned the hunger strike into a mechanism of torture that was meant not to divulge information from the prisoners, but to force them to betray "the principle of solidarity and empathy for their comrades" (ibid.: 243).

These tactics to shock people into submission and break solidarity were learned through historical practice and can be traced to methods used from early colonialism during the Spanish colonization of South America to US Intelligence operations in Latin America in the 1970s and to shock and awe in the US wars on Iraq (Daka 2011: 243). The National Prisoner Movement had built solidarity among Palestinian political prisoners themselves and was a leader in organizing resistance of Palestinians outside of the prisons; thus, solidarity emanated from within and outside of the group. The breaking of solidarity served to end any prisoners' conception of collective action in the future. This occurred in the final blow when the hunger strike ended in a chaotic withdrawal as opposed to the planned, unified and collective decision to end it. Individual prisoners broke the strike across the IPS which ultimately "ensured the total collapse of the leadership structure in prison, as well as the set of shared values which turned soldiers from individuals into fighting units:" the prisoners "were now ready for consciousness molding" (ibid.: 244).

As prisoners quit their strike one by one, independently, the organizers of the National Prisoner Movement realized they had lost their authority and prestige among prisoners, the leadership was defeated, and the prisoners left disorganized and isolated. Under Yaakov Ganot, steps were taken to further break the solidarity of prisoners, atomizing them into individuals and disciplining them into docile bodies. Documented by Daka, the IPS's process to atomize prisoners unfolded through a series of measures. First, prisoners are segregated by their towns and villages coinciding with the Israeli created enclaves, which works to replace the collective 
awareness of a contiguous and unified "Palestine" with individual geographic affiliations. Second, the IPS ceased working with the Dialogue Committees that represented Palestinian prisoners' collective complaints and grievances and replaced it with a system that allocates one spokesman per geographic region. Third, any sign of personal or collective struggle such as refusing a meal is met with mentally debilitating solitary confinement and 23 hours a day isolation. Fourth, all group meetings, excluding Friday prayers, are forbidden and freedom of expression or discussion is denied (any mention of "Palestine" is met with punishment). Fifth, prisoners cannot keep photos of Palestinian leaders or shaheeds (martyrs, any Palestinian killed by the Israeli state) even if the photo is of a family member this will be met with solitary confinement. Sixth, prisoners who are leaders or active in the National Prisoner Movement are transferred to hinder the democratic structure of the movement and further incapacitate solidarity. Seventh, the IPS favorably responds to personal appeals (collective complaints are denied) creating differences in individual living conditions while also collectively punishing prisoners for individual infractions, that together, directs prisoners against one another to struggle for better individual conditions while blaming others for their punishment; thus, they "become agents of the jailing authority, rather than comrades" (2011: 244-246). Palestinian prisoners are being transformed from active political subjects into docile subjects, into consumers, immersed in their individual needs and wants, encouraged by the system that denies them any other way of life (ibid.: 246). Breaking them apart from their collective solidarity, their unified movement, atomizing them, opened them to consciousness re-molding: remaking their soul, remaking their culture. If this is effectively re-molding Palestinian prisoners and breaking the leadership of the Palestinian resistance, what will the future be for Palestinians in the OPTs? 
Atomization beyond the Prison

In 2006, former Israeli chief of staff, Moshe Ya'alon, declared publicly in Israeli media outlets that "the Palestinian consciousness must be remolded, and that this goal dictated his army's plans" (ibid.: 236-237). This declaration was a public statement of the Israeli strategy to defeat Palestinian resistance. The tactics of this strategy include massive and intermittent violence that shocks populations and keeps them in a state of terror, dispossession of Palestinians from their land and means of subsistence through legal procedures and force, and the physical and legal division of Palestinians within the OPTs through a system of walls, checkpoints, and permits. In 2008, when a South African delegation visited Palestine they were appalled by the measures taken by the Israeli government to create a system of apartness: they claimed that the segregation under Apartheid was never as total and absolute; zones of economic and social interactions between whites and blacks always existed (Daka 2011: 236). Even more shocking to the delegation was the structures of separation that not only divided Israelis from Palestinians, but the imposed segregation of Palestinians from each other (ibid.: 236). Before the second Intifada, the revolt of Palestinians against the occupation from 2000-2005, Israel targeted the infrastructure of the resistance movement with the goal of making resistance too costly, but this miserably failed as Palestinian resistance grew in retaliation to the force used by Israel (ibid.: 237). Thus, the tactics and target to destroy Palestinian resistance changed, evident by Moshe Ya'alon's public statement in 2006.

Daka argues that since the end of the second Intifada, "the new targets were the elements of the moral infrastructure of the resistance... the collective values that embodies the concept of one unified people," the target became the very substance that is shared between Palestinians and what makes them Palestinian (ibid.: 237). The three main goals of the current Israeli policy to 
end Palestinian resistance as proposed by Daka are: (1) Palestinian economic, political, and cultural structures and organizations be broken up and disorganized; (2) current political negotiations and international law hearings will continue to produce an illusion that peace is within sight while creating "facts on the ground" (claiming land through colony building in the OPTs) to further complicate the possible "solution;" (3) "[b]reaking up the self-image of a people by destroying Palestinian collective values," through "destroying central forces and groups representing these values, such as the prisoners, the front line of the struggle," and thus reducing Palestinians 'to something less than a nation, but safe from material annihilation" (ibid.: 237). These goals are being realized through the vast system of enclaves that segregate Palestinians from one another, limiting their ability to communicate and contact other Palestinians throughout the OPTs. The enclaves cannot be totally understood in terms of Bantustans in apartheid or ghettoes because they are not merely separate communities, they are in themselves the Israeli solution to Palestinian resistance. The enclaves are an embedded infrastructure of separation and division that suspends Palestinians and immobilizes them, atomizes them. These tactics confirm the process to discipline Palestinians is actively being mobilized while the guise of "peace processes" allows Israel to continue the division and disciplining of Palestinians until they no longer see, or remember, any reason to resist. In the enclave, it is not the Palestinian body that is Israel's main target but Daka as says, it is the Palestinian "soul." It is the very culture of Palestinians that is shared among them and makes them Palestinian that is under attack. 
The Palestinian Soul is the Culture of Palestinians

For Daka to claim that the Palestinian soul is Palestinian culture redefines and complicates Foucault's notion of the soul. Whereas Foucault is primarily concerned with the body and the soul of the individual as the target of discipline, I agree with Daka that this discipline is an assault on, and an attempt to remake culture and is then a continuous struggle to maintain the new social order. In Discipline and Punish, Foucault argues that the soul is not just the creation of Christian theology but is the result of "punishment, supervision, and restraint" of the body (ibid.: 177). The soul is the vector for power to assert control on the body that is influenced by punishment and social boundaries, which ultimately stem from and are defined by culture: culture being defined by the interactions and discursive productions of human bodies together. To separate bodies, physically or discursively, is to cut off the production of culture among them; thus, atomization is the arrest of a given culture production. The unlinking of these bodies pushes them to form new connections and create new meanings. If this occurs in a social hegemony of Foucauldian discipline, they may become new agents of its reproduction. The culture of Palestinians in the OPTs and the prisons inform a different kind of body than the culture of the Israeli state and colonizer's body.

Anthropologist Lars Rodseth has worked to illuminate the conception of culture in the history of Anthropology by reintroducing the theoretical work of Antonio Gramsci. Like Daka, Gramsci wrote much of his work from a prison in a fascist state. He employed the use of the concept of hegemony, not in terms that we normally think that asserts control through force, but control through consent, when discussing culture. Culture to Gramsci was informed by leaders who were granted "spontaneous consent" to "the general direction imposed on social life" (Rodseth 2018: 404). To Gramsci, the ways in which social life are ethically determined by 
groups of people occur by general consent to some members who are seen as leaders or organizers. In the case of Palestinians, their culture has been defined by its leading figures in literature, music, art, and politics that are intertwined with the struggle against Israeli colonization.

Palestinian culture has been a means of resistance to Israeli culture, which has been formed through the discursive othering and demonization of Palestinians that defines Israeli self and society. The feature of "us" and "them," rooted in the discourse of the primitive, defines the settler colonial culture of Israel that has historically sought to claim indigeneity in Palestine. While Palestinians exist under Israeli occupation, the culture of the settlers will never fully be capable of claiming nativeness. The occupation of the OPTs paradoxically renders the settler project of Zionism (in terms of integration/indigenization) impossible (Veracini 2013). Veracini argues that Israel before the 1967 occupation of the West Bank and Gaza, was a successful settler colonial project because the mass expulsion of Palestinians from their land resulted in a settler claim to the "uninhabited" land and an "assimilation" of the few Palestinians who remained (i.e. now Palestinian-Israelis) (2013: 29). Because Palestinians remained in the territories occupied in 1967, Israel was forced to engage in colonial relations once again as the annexation or incorporation of the West Bank and Gaza would result in a major demographic shift: the Jewish "democracy" would no longer be controlled by a Jewish majority. In an attempt to complete the settler project in the OPTs, Israel chose a policy of occupation, segregation, and closure; a means to contain and control Palestinian while colonies are built among their landscape, altering the demographics. Because the occupation seeks to control and monitor every aspect of Palestinian life, it renders the occupied population highly visible, which in turn reinforces the dichotomy between the settler and indigenous: the colonized and the colonizer 
(ibid.: 33). While the occupation is necessary for the success of the colonies, its colonial nature negates and actually reverses the conditions necessary for a successful settler colonial project (ibid.: 32). Veracini points out that the "...the best possible outcome would be the emergence of a docile and, to the extent possible, invisible population" (ibid.: 29). Whereas he goes on to argue that the occupation's efficiency has made this scenario impossible, I posit that atomization is Israel's strategy to overcome this conundrum. The disciplining of politically revolutionary subjects to cultivate acquiescent subjects is a means to absorb them into the settler state but is only effective when they are broken from their collective culture.

The Israeli process to colonize Palestine has incorporated elements of Foucault's discipline through the building of embedded infrastructures that both separate and divide Palestinians from one another and work to control Palestinian life through constant surveillance and punishment. The prison is the laboratory where strategies and tactics are tested before being enlarged and implemented in the OPTs. Daka argues that Israel's current tactics in the IPS are modeled after Foucault's discipline in which power is exerted through the built environment that creates a constant, but indirect monitoring of prisoners and a structure that teaches and ingrains prisoners' boundaries and limitations. The IPS has worked to configure individuals with no political freedom to make collective demands. Instead, prisoners are encouraged and trained to think for themselves, to make requests on behalf of their individual needs and wants. The preoccupation with their own material conditions has effectively rendered them subordinate with little political freedom to reproduce solidarity. Prisoners act as their own jailers, monitoring their own thoughts and speech. Imprisoned by themselves, they have been atomized, broken apart, and disciplined into these positions. This condition was made possible by the initial phases of violence and shock that weakened their morale and engendered chaos amongst their organizing. 
This very process of smashing groups, breaking them apart, and forcing them to act and think in different, individualized ways, often against their group interests, is the process of atomization and discipline that is found throughout the history of European colonialism and the development of capitalism. To further unpack and address atomization, the following section examines the critical contributions of social theorists that challenge white supremacy, capitalism, and colonialism.

Violence, Dispossession, Atomization, and Discipline as Historical and Present In the early 20th century, anthropologist Franz Boas (1920) challenged a dominant discourse that posited humans developed, socially and politically, along a unilineal path of progression. In his 1920 article, “The Methods of Ethnology,” Boas called attention to the "evolutionary point of view" of many scholars including within his own discipline. This view, he argued, "presupposes that the course of historical changes in the cultural life of mankind follows definite laws which are applicable everywhere, and which bring it about that cultural development is... the same among all races and all peoples" (1920: 311). The evolutionary theory of human development assumed that all cultures are fixed to certain laws of progression; thus, human societies "progress" through stages that "begin" as primitive and "end" with advanced civilization as self-exemplified by the European powers of the time. In response to the evolutionary theory, Boas points to ethnographic evidence that shows cultures as existing in a constant state of flux subject to various forces internally and externally (1920). Instead of cultures progressing to civilization, they are all in dynamic processes that could lead nomads to settle or civilizations to disperse. All cultures, societies, systems, and ideologies of the present, whether the present in Boas' time or ours now, are informed by historical processes. Our reality 
is a dynamic process of interacting dialectics of discourse and practice of people and the environment. Whether to atomize, to discipline, to dominate, to unify, to illuminate, to liberate are determined by the historical processes that precede the present. The prevalent theory of unilineal evolution of the early 20th century was arguably not a new development or theoretical discovery as much as it was a re-postulation of a long-standing discourse found in European thought.

Beginning his book by discussing the various historical interpretations of social change and the affinity for it to be aligned with growth, Thomas C. Patterson (2018) illustrates the historical dialectic between discourse and practice that justified European colonialism and later, informed industrial capitalism. Throughout European history, from the ancient Greeks to the English under Queen Victoria and today, change has been argued as either a cyclical process or as constant growth. Patterson argues that it was in the period known as The Enlightenment that scholars began to periodize history, setting each time period on a line that posited constant growth from the past to the present. Change became accepted as growth and progress, "endorsed by those who saw themselves benefiting from emerging structures of power relations" (2018: 21). The ruling classes in Europe experienced a vast consolidation of power and wealth as they colonized and plundered the "less developed" world. Here, the dialectic of economic expansion and theoretical acceptance of change as growth reinforced one another feeding into the development of capitalism. Economic, social, and political realities exist in a dialectic with the theories and discourses that circulate, working to bolster one another or alternatively, to undermine and defeat the reproduction of any given time's present reality. Thus, change occurs through time as a constant struggle between forces, between people, to determine present reality. 
The historical acceptance and reproduction of change as growth has informed and justified our contemporary economic condition of capitalism and more specifically, neoliberalism.

Karl Marx observed the crisis unfolding throughout Europe as nations were increasingly industrializing and the political-economic system of capitalism was expanding. Marx worked to define capitalism and ultimately, in Capital (1867), established the grounds to argue that capitalism was a system of exploitation. He documented the ways in which capitalists, those who own the means of production and possess capital, or money to invest with the expectation of a profit return, extracted value from their workers. This occurs by the commodification of labor and the use of wages to pay for workers' labor power that ultimately produces value in the final product and the capital of the capitalist (1976[1867]: 342). Laboring bodies become commodities that can be bought and sold and produce value, or profit, for the capitalists. It is the interest of the capitalist to extract as much surplus labor from the worker as possible in order to produce the highest use-value of their commodity, the worker (ibid.: 342). In his other work, Karl Marx recognized that the power of the workers was located in their ability to stop capital in its tracks by ceasing to work but this required unity and solidarity between them. This suggests that workers were atomized under capitalism, possibly working for their own individual interests to perhaps get a raise or out of fear of punishment; both discipline and atomization worked together to keep them in line and to keep them weakened. But what events led to this condition? Capitalism as a system of exploitation required some degree of domination: why would workers willingly give up their labor power for, as Marx witnessed, low pay and poor conditions?

Pulling the thread that runs throughout discussions and arguments of capitalism, colonialism, and white supremacy, the foundational work of Silvia Federici (2014) reveals a long history marked by atomization. Her analysis of the development of capitalism in 16th century 
Europe illustrates the historical continuity and modularity of colonialism and capitalism. This provides the foundational argument that the colonization and occupation of Palestine is inherently connected to the exploitation of workers in the capitalist world and the intersecting oppressions of racism, sexism, transphobia, homophobia, anti-Semitism, and the like. These are tied together through the means that render these groups powerless in the face of domination and exploitation. Federici illustrates that the discursive production of civilized and primitive maps onto numerous reformulations that work to justify and moralize subjugation by one group over another. Hierarchies and systems of domination are then reproduced by the very people who are oppressed by them: what Daka (2011) calls the remolding of consciousness. Federici begins in an epoch of European history often overlooked as a period of cultural and social decline.

As a result of the Black Death (1347 - 1351), much of the peasantry and workers of Europe found themselves in a period of unprecedented power because of the scarcity of labor and competing employers (Federici 2014: 46). Between 1350 and 1500 was a period of disaccumulation and worker empowerment. Rent was low, real wage increased by $100 \%$, goods were cheap, the working day decreased, and local self-sufficiency became common. As quoted by Marx (1909: 789) this new standard allowed for the "wealth of the people," but "excluded the possibility of capitalistic wealth" (ibid.: 62). This produced a period of egalitarian relations between workers, peasants, and aristocrats, not because the ruling class desired this, but because they were forced to abdicate to the few workers left to produce commodities and food. The value of labor was made real and apparent, empowering workers and disempowering aristocrats. In response, the ruling classes organized a revolution against egalitarian relations as a means to amass wealth at the expense of the world. This would take place over hundreds of years but 
follows a similar pattern to the colonization of Palestine: the accumulation of land, bodies, and souls would make the foundations of the new capitalist and colonial order.

The ruling class revolution to create a new economic model began with the accumulation of land, paralleling the initial colonization of Palestine. The collective lands used by peasants to create a self-sustaining economy known as the commons, were seized by the aristocrats through policies known as enclosure: “[I]n the 16th century, 'enclosure' was a technical term, indicating a set of strategies the English lords and rich farmers used to eliminate communal land property and expand their holdings" (Federici 2014: 69). Enclosure was the physical walling of the commons, or collectively used land, and the eviction of peasants in order to claim private property rights (ibid.: 70). The argument against collective agriculture and the commons was that it was a backwards, primitive, and inefficient model (ibid.: 70). The same discourse utilized by Zionists to make claims to Palestinian land. Federici, highlighting the importance of the commons to the egalitarian relations formed during this period, writes, “[B] esides encouraging collective decision-making and work cooperation, the commons were the material foundation upon which peasant solidarity and sociality could thrive" (ibid.: 71). The commons were a source of social solidarity that united the workers and empowered them, especially women.

The destruction of the commons shattered the social cohesion of the communities that functioned with a cooperative and communal focused "primitive communism" (ibid.: 72). Families collapsed as young people left the home searching for jobs since their livelihoods could no longer be sustained by collective work. This left much of the elderly, mostly women, left to fend for themselves. During this period of enclosure, uprisings against the privatization of land were commonly led by women who saw their stakes being the highest - the loss of the commons and equal association amongst the sexes would spell their disempowerment. 
The women-led peasant revolts to stop the privatization of land led to state intervention on behalf of the ruling class. This included a discursive project to demonize women as witches, which coincided with the demonization of indigenous people in the colonies, and sexual policy reforms to encourage violence against them. This paved the way for the witch-hunts that would destroy the memory of the previous violence of the ruling class during the enclosures and would shock women into being a source of free labor and its reproduction. By the end of the $15_{\text {th }}$ century a counter-revolution by the ruling classes was underway through breaking apart the working class through sexual politics. Targeted towards the rebellious and young male workers, this "turned class antagonisms into an antagonism against proletarian women" (ibid.: 47). This in turn created an intense climate of misogyny that degraded women of all social standings and "desensitized the population to the perpetration of violence against women preparing the grounds for the witch-hunt which began in this same period" (ibid.: 48-49). In France and Italy, statefunded brothels became common and even the Church, which maintained much political and economic power in this era, came to view prostitution as a legitimate activity. State sanctioned violence against women served to “...discipline and divide the medieval proletariat" while simultaneously empowering the state to be the broker of class relations (ibid.: 49). In the colonies, the demonization of the American indigenous people served to warrant their enslavement and disposal. In parallel fashion, “... the attack waged on women justified the appropriation of their labor by men and the criminalization of their control over reproduction" (ibid.: 102). Resistance would be meant with extermination, justified by discourses of the witch, heretics, primitives, and demons (ibid.: 102).

The response of the bourgeoisie and the aristocrats of Europe to the demographic crisis that forced them into egalitarian relations links capitalism and colonialism to primitive 
accumulation and slavery. In South America, a century after the Spanish conquest, the indigenous population declined by 75 million representing 95 percent of its inhabitants (ibid.: 85 86). While the colonies were being depopulated, the European population was declining as well. The European ruling class was experiencing a demographic crisis that threatened their ability to rapidly accumulate wealth. The response to the crisis in Europe was the subjugation of women; while in the colonies, the slave trade began. It would be the plantation system in the Americas that birthed the Industrial Revolution (ibid.: 103). Arguably, it was not European capitalists or aristocrats who built industrial capitalism, but the slaves in the colonies, the workers in Europe, and the women who were forced to bear them. "The expropriation of European workers from their means of subsistence, and the enslavement of Native Americans and Africans to the mines and plantations of the New World, were not the only means by which a world proletariat was formed and 'accumulated;"' this would include the violent subjugation of women and the commodification of the worker's body to serve sex-divided functions in a hierarchy of the capitalist economic system (ibid.: 63) This is the story of primitive accumulation and the creation of capitalism: brutal violence. The connections between colonialism and capitalism are evident in this past and are continuously reproduced in the present as Israel attempts to accumulate the Palestinian territories through whatever means necessary.

Federici speaks to atomization as the ruling classes' means to quell resistance and normalize the new social order writing, "[P]rimitive accumulation, then, was not simply an accumulation and concentration of exploitable workers and capital. It was also an accumulation of differences and divisions within the working class, whereby hierarchies are built upon gender, as well as 'race' and age, became constitutive of class rule and the formation of the modern proletariat” (2014: 63-64). She continues with, “... capitalism has created more brutal and 
insidious forms of enslavement, as it has planted into the body of the proletariat deep divisions that have served to intensify and conceal exploitation" (ibid.: 64). The discursive and physical war waged on the working class broke them apart and crystallized a structure of hierarchy that ultimately reproduces itself. The process of primitive accumulation in 16th century Europe, which incorporated atomization as a strategy to ensure acquiescence of the oppressed, has never truly ended because of the cyclical nature of capitalism as proposed by Federici: “... periodically, but systematically, whenever the capitalist system is threatened by a major economic crisis, the capitalist class has to launch a process of "primitive accumulation" that is a process of large-scale colonization and enslavement, such as the one we are witnessing at present (Bates 1999)" (ibid.: 104). The historical atomization of the working class and indigenous people has worked to destroy solidarity, making power inaccessible to the masses in the present as these relations of hierarchies and oppressions have been normalized. 


\section{CONCLUSION: ATOMIZATION AND SOLIDARITY}

Atomization, the process of breaking solidarity amongst a people, opens the possibility for the restructuring of the dominated groups' consciousness. Their consciousness is their awareness of the material world around them, which is socially produced by the group and through various external factors and powers; be it the environment or a colonizing people. This is shown through the work of Silvia Federici (2014) who explored the development of capitalism through primitive accumulation. Through the ruling classes' revolution, working class consciousness changed to adapt to capitalist relations in which exploitation, violence, hierarchy, and oppression were normalized. Where there is effective primitive accumulation, there is a strategy of atomization. This is the mission of the colonial state of Israel: to finally force Palestinians into colonial and capitalist relations that they will not resist. If atomization is the process of breaking solidarity, then clearly the means to overcome it are found in the ways people maintain and build solidarity.

The Popular Front for the Liberation of Palestine (PFLP), a Marxist-Leninist revolutionary party that Walid Daka was a member of before being imprisoned, writes in its program, A Strategy for the Liberation of Palestine:

"[T]he Palestinian revolution, which is fused together with the Arab revolution and in alliance with world revolution is alone capable of achieving victory. To confine the Palestinian revolution within the limits of the Palestinian people would mean failure, if we remember the nature of the enemy alliance which we are facing (1969:45)

The party recognized that victory for an egalitarian socialist state "in which both Arabs and Jews will live as citizens with equal rights and obligations," can only be won through unity, by defying atomization and struggling against the unified forces of imperialism and colonialism 
(ibid.: 43).When I attended the 2019 National Students for Justice in Palestine conference, a nation-wide student led group in the United States, the theme was "united struggle." Throughout the building posters and murals declared: “Our Struggles are United!” Panelists and speakers addressed the various ways that trans liberation, worker liberation, and Palestinian liberation were connected and apart of the same struggle. This kind of political unity, this solidarity, is what will effectively defy atomization and discipline in the OPTs and the world. It will be through the various and vast groups of people who recognize that the Palestinian struggle is a part of their own and should be fought on the same grounds. Solidarity will be the only way to change the current order of the world that is characterized by domination and exploitation.

The history of humanity is not, as Boas argued, a unilineal path of growth and development, instead it is wanes and waxes; it is motions between different social relations and societal organizations. Humanity can be characterized by domination and exploitation such as in capitalist societies or they can be marked by egalitarian and communal relations such as in hunter and gatherer societies or possibly in the socialist societies described by revolutionaries fighting for a different reality. Bruce Trigger argues that human nature is not inherently good or inherently bad, instead our "nature" is constantly shaped and formed through the ability for human agents to make their own worlds. A dialectic between our agency as people and the structures we make produce our relations and reproduce our "goodness" or our "badness." This dialectic is the constant and present struggle we, as in the people who are subjected by capitalist forces, are facing. As Patterson (2005 and 2018) reminds us, we must look to the past to find answers to our present and to inform the possibilities of our future. Perhaps, through remembering and reproducing solidarity, atomization will not be a part of our near future. 


\section{REFERENCES}

Abdelnour, Samer, Tartir, Alaa and Zurayk, Rami. 2012. "Farming Palestine for Freedom." Policy brief. Washington D.C.: al-Shabaka

Al-Haq, Law in the Service of Man (Ramallah). 1988. Punishing a Nation: Human Rights Violations during the Palestinian Uprising: December 1987-December 1988.

Benvenisti, Meron. 2000. Sacred Landscape: The Buried History of the Holy Land Since 1948. Berkeley: University of California Press.

Bernstein, Henry. April 2015. "Food Regimes and Food Regime Analysis: A Selective Survey." BRICS Initiative for Critical Agrarian Studies (BICAS).

Boas, Franz. 1920. "The Methods of Ethnology” American Anthropologist (N.S.) 22 (4):311321.

Calis, Irene. 2017. "Routine and Rupture: The Everyday Workings of Abyssal (Dis)order in the Palestinian Food Basket." American Ethnologist, (44) 1: 65-76.

Campos, Michelle. 2010. Ottoman Brothers: Muslims, Christian, and Jews in Early Twentieth-Century Palestine. Stanford: Stanford University Press.

Canaan T. 1931. "Light and Darkness in Palestinian Folklore." Journal of the Palestine Oriental Society. 11:15-36.

Cohen, Dan. 2014. "In the Last Days of 'Operation Protective Edge' Israel Focused on Its Final Goal- the Destruction of Gaza's Professional Class." Mondoweiss. https://mondoweiss.net/2014/10/protective-destruction-professional/.

Daka, Walid. 2011. "Consciousness Molded or the Re-identification of Torture" In Threat: Palestinian Political Prisoners in Israel, Abeer Baker and Anat Matar (eds.), 234-53. London: Pluto.

Drobles, Mattiityahu. 1980. Master Plan for the Development of Settlement in Judea and Samaria (1979-1983). Jerusalem: World Zionist Organization.

Durkheim, Émile. 1972 [1893]. "Forms of social solidarity; The division of labour and social differentiation" In Anthony Giddens (ed.) Émile Durkheim: Selected Writings, 123-154. Cambridge: Cambridge University Press. 
Dyke, Joe. 2014. "Analysis: Donors Threaten to Withhold Gaza Aid." IRIN:

Humanitarian News and Analysis. October 7. https://www.un.org/unispal/document/autoinsert-208520/.

Edidin, Ben M. 1944. Rebuilding Palestine. Rev. ed. New York: Behrman House.

Elkins, Caroline and Susan Pedersen, eds. 2005. Settler Colonialists in the 20th Century: Projects, Practices, Legacies. New York: Routledge.

Federici, Silvia. 2014. Caliban and the Witch: Women, the Body, and Primitive Accumulation. New York: Autonomedia.

"Food Security Statistics.” FAO Official Website. Accessed December 8, 2018. http://www.fao.org/economic/ess/ess-fs/en/

Foucault, Michel. 1984 [1975]. "The Body of the Condemned; The Means of Correct Training" In Paul Rabinow (ed.) The Foucault Reader, 170-187; 188-205. New York: Pantheon Books.

Furani, Khaled and Dan Rabinowitz. 2011. "The Ethnographic Arriving of Palestine" Annual Review of Anthropology, 40: 475-491.

Gasteyer, Stephen P., and Cornelia Butler Flora. 2000. "Modernizing the Savage: Colonization and Perceptions of Landscape and Lifescape.” Sociologia Ruralis, 40 (1): 128-49.

Hass, Amira, and Ido Efrati. 2014. "Gaza's Water System Collapsing Due to IDF Strikes, Says Red Cross." Haaretz. July 16. https://www.haaretz.com/.premium-red-crossgaza-water-system-collapsing-1.5255621.

Herzl, Theodor. 1902. The New Old Land. [Altneuland, 1902], Lotta Levensohn, trans. New York: M. Wiener 1941.

"Humanitarian Needs Overview. 2018. " UN Office for the Coordination of Humanitarian Affairs." https://www.ochaopt.org/sites/default/files/hrp_2018_dashboard.pdf

Jamjoum, Lama. 2002. "The Effects of Israeli Violations During the Second Uprising 'Intifada' on Palestinian Health Conditions." Social Justice, 29 (3): 53-72.

Khalidi, Walid. 1988. "Plan Dalet: Master Plan for the Conquest of Palestine." Journal of Palestine Studies. 18(1): 4-33.

Khalili, Laleh. 2013. Time in the Shadows: Confinement in Counterinsurgencies. Stanford, CA: Stanford University Press. 
Kuper, Adam. 2005. The Reinvention of Primitive Society: Transformations of a Myth. Milton Park, Abingdon, Oxon: Routledge.

Lerski, Helmar, Paul Dessau, Tobis Klangfilm, SinemațekYerushalayim, and Israel Film Archive, dirs. 2009. Awodah. Jerusalem Cinematheque, Israel Film Archive.

Li, Darryl. 2006. "The Gaza Strip as Laboratory: Notes in the Wake of Disengagement." Journal of Palestine Studies. XXXV (2) (Winter): 38-55

Lutfiyya AM. 1966. Baytin—a Jordanian Village. A Study of Social Institutions and Social Change in a Folk Community. The Hague: Morton.

Makovsky, David. 2004. "How to Build a Fence.” Foreign Affairs 83 (2): 50-64

Marx, Karl. 1976 [1867]. "The Working Day.” In Capital: A Critique of Political Economy, Volume One, pp. 340-374. New York: Penguin Books.

1909 [1867]. Capital: A Critique of Political Economy. Vol. 1 and Vol 3. Chicago: Charles H. Kerr and Company.

Mbembe, Achille. 2003. "Necropolitics." Translated by Libby Meintjes. Public Culture 15(1): 11-40.

Moors, Annelies. 1995. Discourse and Palestine: Power, Text and Context. Amsterdam: Het Spinhuis.

Nakhleh K. 1975. "The Direction of Local-level Conflict in two Arab Villages in Israel." American Ethnology. 2: 497-517.

Ortner, Sherry B. 2016. "Dark anthropology and its others: Theory since the eighties." HAU: Journal of Ethnographic Theory 6(1): 47-73.

Otero, Gerardo, Gabriela Pechlaner, and Efe Gürcan. 2013. "The Political Economy of 'Food Security' and Trade: Uneven and Combined Dependency." Rural Sociology, 78(3): 263-289.

Patterson, Thomas C. 2005. "The Turn to Agency: Neoliberalism, Individuality, and Subjectivity in Late-Twentieth-Century Anglophone Archaeology" Rethinking Marxism 17(3): 373384.

------- 2018. Social Change Theories in Motion. New York: Routledge. 
Peteet, Julie Marie. 2017. Space and Mobility in Palestine. Public Cultures of the Middle East and North Africa. Bloomington: Indiana University Press.

------ 2005. Landscape of Hope and Despair: Palestinian Refugee Camps. (The Ethnography of Political Violence.) Philadelphia: University of Pennsylvania Press.

Popular Front for the Liberation of Palestine. 1969. A Strategy for the Liberation of Palestine. Amman, Jordan: Information Department.

Pugliese, Joseph. 2015. "Forensic Ecologies of Occupied Zones and Geographies of Dispossession: Gaza and Occupied East Jerusalem.” Borderlands e-journal 14(1): 1-37.

Puar, Jasbir K. 2017. The Right to Maim: Debility, Capacity, Disability. Durham and London: Duke University Press.

Rami Zurayk, Anne Gough, Ahmad Sourani, and Mariam Al Jaajaa. 2012. "Food Security Challenges and Innovation: The Case of Gaza." The Arab Group for the Protection of Nature. September.

Reinhart, Tanya. 2002. Israel/Palestine: How to End the War of 1948. New York: Seven Stories.

Rodseth, Lars. 2018. "Hegemonic Concepts of Culture: The Checkered History of Dark Anthropology” American Anthropologist 120(3): 398-411.

Robinson, Shira. 2013. Citizen Strangers: Palestinians and the Birth of Israel's Liberal Settler State. Stanford, CA: Stanford University Press.

Rosenfield, Maya. 2011. "The Centrality of the Prisoners' Movement to the Palestinian Struggle against the Israeli Occupation: A Historical Perspective.” In Threat: Palestinian Political Prisoners in Israeli, edited by Abeer Baker and Anat Matar, 3-24. London: Pluto.

Roy, Sara. 1999 "De-Development Revisited: Palestinian Economy and Society since Oslo." Journal of Palestine Studies XXVIII (3): 64-82. Spring.

Said, Edward. 1978. Orientalism. London: Penguin. 1979. The Question of Palestine. New York: Times.

Said, Hashem and Ehab Zahriyeh. "Gaza’s Kids Affected Psychologically, Physically by Lifetime of Violence." Al Jazeera. July 31, 2014. http://america.aljazeera.com/articles/2014/8/1/health-gaza-children.html.

Salamanca, Omar Jabary. 2011. "Unplug and Play: Manufacturing Collapse in Gaza.” Human 
Geography 4(1): 22-37.

Saranillio, Dean Itsuji. 2015. "Settler Colonialism.” In Native Studies Keywords, Stephanie Nohelani Teves, Andrea Smith, and Michelle H. Raheja (eds.) 284-300. Tucson: University of Arizona Press.

Sayigh, Rosemary. 1979. Palestinians: From Peasants to Revolutionaries: A People's History. London: Zed Press.

Smith, Andrea. 2012. "Indigeneity, Settler Colonialism, White Supremacy." Racial Formation in the Twenty-First Century, edited by Daniel Martinez HoSang et al., 66-90. Berkeley" University of California Press.

Swedenburg, Ted. 1989. "Occupational Hazards: Palestine Ethnography." Cultural Anthropology. 4: 265-72.

1990. “The Palestinian Peasant as a National Signifier. Anthropological Quarterly. 63: 18-30.

Trigger, Bruce. 2006. "All People Are (Not) Good." In Jacqueline Solway, (ed.), The Politics of Egalitarianism: Theory and Practice. 21-29. New York: Berghahn Books.

Veracini, Lorenzo. 2013. "The Other Shift: Settler Colonialism, Israel, and the Occupation." Journal of Palestine Studies 42(2): 26-42.

Weizman, Eyal. 2007. Hollow Land. Israel's Architecture of Occupation. London: Verso

Weber, Max. 1946 [1922]. "The Sociology of Charismatic Authority; The Meaning of Discipline; The Protestant Sects and the Spirit of Capitalism." in H. H. Gerth and C. Wright Mills, (eds.), From Max Weber: Essays in Sociology, 245-252; 253-264; 302-322. New York: Oxford.

“WFP Palestine Country Brief.” 2018. World Food Programme Palestine. October. https://docs.wfp.org/api/documents/WFP0000100648/download/?.ga=2.53264872.1100238156.1544306003934345517.1544306003

Wolfe, Patrick. 2006. "Settler Colonialism and the Elimination of the Native." Journal of Genocide Research 8(4): 387-409.

Zurayk, Rami and Anne Gough. 2013. Control Food, Control People: The Struggle for Food Security in Gaza. Washington, D.C.: Institute for Palestine Studies. 


\section{CURRICULUM VITAE}

\section{Christian Alexander Brawner}

525 Belgravia Ct. Apt 1 Louisville, KY 40208

Cell: (270) 304-8480 Email: christian.brawner@ louisville.edu

\section{Education}

Université Moulay Ismail, Morocco. Spring 2014

Visiting scholar studying Modern Standard Arabic, Politics of the Middle East, and

Peace, Justice, and Transformation

University of Louisville, KY (2012 - 2016)

B.A. Cultural/Social Anthropology

Minor in Middle East and Islamic Studies

Milestone: Honor's Scholar

University of Louisville, KY (2018 - Present)

M.A. Cultural/Social Anthropology

Focus: Capitalism and Colonialism, Solidarity and Resistance, Palestine

Expected graduation: May 2020

\section{Honors/Distinctions}

Trustees' Scholarship, University of Louisville, 2012-2016

Frederic Hicks Anthropology Travel Award, University of Louisville, Spring 2014

International Center Scholarship, University of Louisville, Spring 2014

Department of Anthropology Award of Merit, University of Louisville, Spring 2016

Critical Language Scholarship, Morocco, U.S. Department of State, Summer 2016

Fulbright English Teaching Assistant Recipient, U.S.-Jordan Fulbright Commission, 2016-2017

Graduate Dean's Citation, M.A. Anthropology, University of Louisville, Spring 2020

\section{Work/Research Experience}

Graduate Assistant, Louisville, Kentucky 2018-Present

Working in the Office of Student Involvement at the University of Louisville as an assistant administrator to the Assistant Director of Student Involvement. Overseeing and facilitating over 500 Recognized Student Organizations (RSOs) as the Graduate Chair of the Student Government Association's Student Organization Advisory Board (SOAB). Serving as a community administrator of the UofL student engagement website Engage. Developing and implementing assessment outcomes and instruments for RSO-related programs, services, and events.

Research Assistant, AAA Taskforce, Louisville, Kentucky Summer 2019 - Fall 2019 Assisting in the production of a bibliography concerning mobility, walls, and borders in the Middle East for the American Anthropological Association alongside my supervising 
professor. Consisted of reading through related and up to date research and completing annotations for each entry. Final document used for continued research by the American Anthropological Association (AAA) taskforce.

Research Assistant, Reading Kanafani in Kentucky, Louisville, Kentucky 2018-2019 Eliciting community conversation to Ghassan Kanafani's play Returning to Haifa in exploring the meanings of home, belonging, and loss in the context of displacement, migration, and refugee resettlement. This project will seek to unite and engage disparate communities within Louisville Kentucky, that have experienced forced displacement through state intervention, and now share a common starting point from which to share their stories, organize, and co-create ameliorative strategies and demands for restitution, resettlement, and justice. Research supported by the University of Louisville's Cooperative Consortium for Transdisciplinary Social Justice Research in partnership with the Fellowship of Reconciliation, Kentucky Refugee Ministries, and LFPL.

VISTA Americorps, Louisville, Kentucky, 2017-2018

Serving at KentuckianaWorks as labor market intelligence research assistant and project assistant to the deputy director. Analyze and interpret data concerning the labor force and employers in the Louisville MSA. Assist in the design, facilitation, and execution of projects such as developing a standard method for foreign educated nurses to obtain licensure in Kentucky and training career centers in its implementation.

Fulbright English Teaching Assistant, Amman, Jordan, 2016-2017

Awarded by the J. William Fulbright Foreign Scholarship Board (FFSB) and the Fulbright Jordan Commission through a highly selective competition. Facilitated English language acquisition in ninth-grade classes at an U.N.R.W.A. registered school for Palestinian refugees. Studied colloquial Jordanian/Palestinian Arabic in a formal class setting at a language institution and received private tutoring.

Americorps Bonner Leader, University of Louisville, 2014-2015 Assigned as an ESL teaching intern at Kentucky Refugee Ministries. Furthermore, attended biweekly, every other Friday, lectures focused on social and economic justice issues in the local community of Louisville.

ESL Teaching Intern, Kentucky Refugee Ministries, 2014-2015

Assisted in teaching an intermediate English class by means of small group activities and teaching half of the class in a separate room to provide a smaller class environment.

Served as office staff helping complete administrative work. Assignment was three times a week for three hours.

ESL After School Intern, Americana Community Center, 2012-2013

Assisted immigrant and refugee children with after-school homework and helped keep the community library organized two times a week for three hours.

\section{Languages}

English, Native Proficiency

Jordanian/Palestinian Colloquial Arabic, Intermediate Proficiency

Modern Standard Arabic, Intermediate Proficiency 